\title{
Cellular pathways for viral transport through plasmodesmata
}

\author{
Annette Niehl • Manfred Heinlein
}

Received: 9 September 2010 /Accepted: 16 November 2010 /Published online: 2 December 2010

(C) Springer-Verlag 2010

\begin{abstract}
Plant viruses use plasmodesmata (PD) to spread infection between cells and systemically. Dependent on viral species, movement through PD can occur in virion or non-virion form, and requires different mechanisms for targeting and modification of the pore. These mechanisms are supported by viral movement proteins and by other virus-encoded factors that interact among themselves and with plant cellular components to facilitate virus movement in a coordinated and regulated fashion.
\end{abstract}

Keywords Plasmodesmata - Virus · Movement protein .

Cytoskeleton - Endoplasmic reticulum .

Silencing suppressor

$\begin{array}{ll}\text { Abbreviations } \\ \text { AbMV } & \text { Abutilon mosaic virus } \\ \text { AMV } & \text { Alfalfa mosaic virus } \\ \text { BDMV } & \text { Bean dwarf mosaic virus } \\ \text { BMV } & \text { Brome mosaic virus } \\ \text { BYV } & \text { Beet yellows virus } \\ \text { CaMV } & \text { Cauliflower mosaic virus } \\ \text { CMV } & \text { Cucumber mosaic virus } \\ \text { CPMV } & \text { Cowpea mosaic virus } \\ \text { GFLV } & \text { Grapevine fanleaf virus }\end{array}$

Handling Editor: Alexander Schulz

A. Niehl $\cdot$ M. Heinlein

Institut de Biologie Moléculaire des Plantes du CNRS,

Université de Strasbourg,

12 rue du Général Zimmer,

67084, Strasbourg, France

M. Heinlein $(\bowtie)$

Botanical Institute, Department of Plant Physiology,

University of Basel,

Hebelstrasse 1,

CH-4056, Basel, Switzerland

e-mail: manfred.heinlein@ibmp-cnrs.unistra.fr

\begin{tabular}{|c|c|}
\hline GRV & Groundnut rosette virus \\
\hline PMTV & Potato mop-top virus \\
\hline PPV & Plum pox virus \\
\hline PsbMV & Pea seed-borne mosaic virus \\
\hline PVX & Potato virus $X$ \\
\hline PVY & Potato virus $Y$ \\
\hline TCrLYV & Tomato crinkle leaf yellows virus \\
\hline TEV & Tobacco etch virus \\
\hline TGMV & Tomato golden mosaic virus \\
\hline TLCV & Tomato leaf curl virus \\
\hline TMV & Tobacco mosaic virus \\
\hline ToMV & Tomato mosaic virus \\
\hline TSWV & Tomato spotted wilt virus \\
\hline TVCV & Turnip vein clearing virus \\
\hline WClMV & White clover mosaic virus \\
\hline $\mathrm{CP}$ & Coat protein \\
\hline EB1 & Microtubule end-binding protein 1 \\
\hline ER & Endoplasmic reticulum \\
\hline HC-Pro & Helper component-protease \\
\hline HR & Hypersensitive response \\
\hline HSF & Heat-shock factor \\
\hline MP & Movement protein \\
\hline MT & Microtubules \\
\hline NCAP & Non-cell-autonomous protein \\
\hline NIG & NSP-interacting ATPase \\
\hline NSP & Nuclear shuttle protein \\
\hline PD & Plasmodesmata \\
\hline PDLP & Plasmodesmata-localized protein \\
\hline PME & Pectin-methylesterase \\
\hline vRNA & Viral RNA \\
\hline RDR & RNA-dependent-RNA polymerase \\
\hline RISC & RNA-induced silencing complex \\
\hline RNP & Ribonucleoprotein complex \\
\hline SEL & Size exclusion limit \\
\hline TGB & Triple gene block \\
\hline VRC & Viral replication complex \\
\hline
\end{tabular}




\section{Introduction}

Plant viruses cause systemic infection of their hosts by cell-to-cell movement through plasmodesmata (PD) and by movement between organs via the phloem (Fig. 1). Since viruses can be easily manipulated in vitro, they represent excellent keys to the molecular mechanisms that govern intercellular macromolecular trafficking and intercellular communication through PD (Heinlein 2002a,b; Heinlein and Epel 2004). Communication through PD indeed involves the controlled cell-to-cell and systemic trafficking of a whole range of RNA and protein macromolecules, including non-cell-autonomous transcription factors, RNA-silencing signals, and messenger RNAs (Dunoyer et al. 2005; Haywood et al. 2002; Heinlein 2002a; Heinlein 2005; Heinlein and Epel 2004; Huang et al. 2005; Ishiwatari et al. 1998; Kim 2005; Kurata et al. 2005; Kehr and Buhtz 2008; Lucas et al. 2001; Lucas et al. 2009; Tzfira et al. 2000; Wu et al. 2002; Yoo et al. 2004). Thus, studying the mechanisms underlying virus movement provides important insights into the functioning of the plant organism as a whole, into the mechanisms involved in the orchestration of systemic defense and adaptation reactions, and into the mechanisms involved in viral pathogenesis.

\section{General mechanisms governing or restricting virus spread within the plant}

Infection is a complex process that depends on coordinated and balanced interactions between virus- and plant-encoded factors. Because of this complexity, systemic virus infection is usually limited to a certain range of plant host species. For example, whereas some host species support systemic movement of a given virus, other hosts may restrict the virus to the inoculated leaves or even to the initially inoculated cell. Viruses that are successful in producing systemic infections may still not be able to infect all host tissues. Since viruses move in the phloem with the flow of photoassimilates, infection first spreads into physiological sink tissues. Thus, as leaves mature and undergo the sinkto-source transition in photoassimilate import, there is a progressive decline in the amount of photoassimilate and virus entering the lamina so that, in more mature source leaves, only the base of the leaf becomes infected. In addition to changes in photoassimilate transport the sink-tosource transition may pose additional barriers for efficient virus movement because of structural and functional differentiation of PD. Whereas PD in sink tissues have a simple, primary structure and a rather large size exclusion limit (SEL) allowing the free diffusion of macromolecular
Fig. 1 Spread of TMV infection in N.benthamiana visualized with a TMV derivative expressing GFP under control of the CP subgenomic promoter. $\mathbf{a}$ and $\mathbf{b}$ Cell-to-cell spread of infection in the inoculated leaf. The virus spreads radially in the epidermis and mesophyll, and finally reaches the vasculature. $\mathbf{c}$ In the vascular phloem, the virus is transported to non-inoculated, systemic leaves where it continues cell-to-cell spread. Arrowheads inoculated leaves, arrows infected systemic leaves
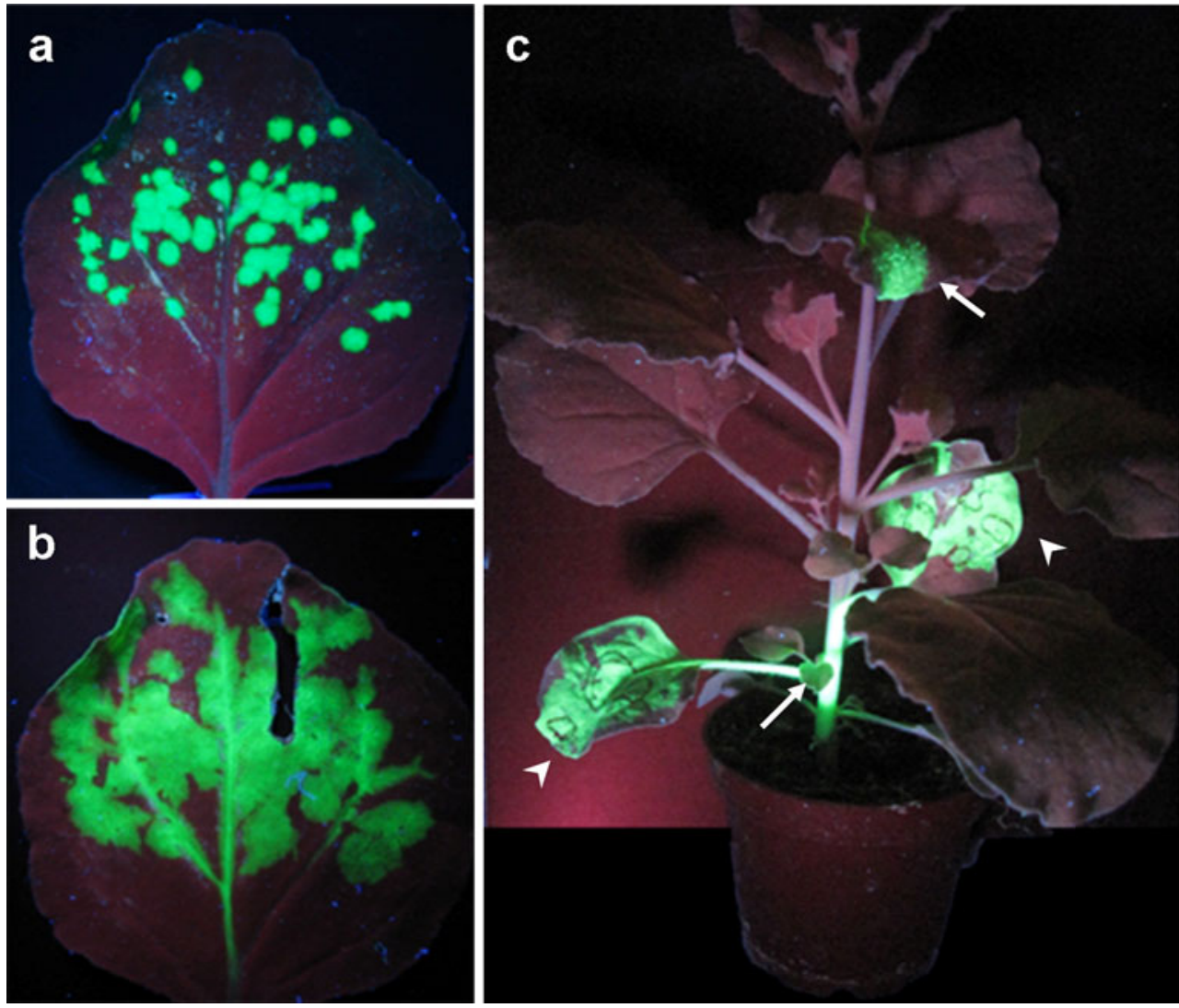
probes such as green fluorescent protein (GFP), the PD in source tissues have a complex, branched secondary structure, and a restricted SEL (Oparka et al. 1999). Although the ability of viruses to invade plants and to cause systemic infection is principally dependent on viral and cellular factors supporting virus replication and movement, the outcome of the infection is also determined by antiviral plant defenses and the ability of the viruses to either suppress or evade them, or to overcome them by evolution. An important antiviral defense strategy of plants is the specific recognition of viral effector proteins by resistance gene products and subsequent initiation of a hypersensitive response (HR) leading to cell death. This cell death response prevents further spread of the virus thus restricting infection to the initially infected cells. Moreover, as a second layer of defense, the HR produces a non-cellautonomous signal leading to systemic acquired resistance that provides non-specific protection against a wide spectrum of pathogens (Durrant and Dong 2004). Another important non-cell autonomous defense mechanism is RNA silencing that can propagate cell-to-cell through PD and degrades viral RNA (Baulcombe 2004; Ding and Voinnet 2007).

Viruses encode proteins required for their replication, intercellular movement, silencing suppression, and encapsidation. A minimal set of genes essential for systemic viral infection is encoded, for example, by the genome of Tobacco mosaic virus (TMV; Heinlein 2002b). This virus encodes two subunits of replicase (the $126 \mathrm{k}$ and $183 \mathrm{k}$ proteins), a $30-\mathrm{kD}$ movement protein (MP), and a $17.5-\mathrm{kD}$ coat protein $(\mathrm{CP})$. The replicase is required for replication of the positive-sense, single-stranded RNA genome of the virus (for review, see Buck 1999), is directly or indirectly involved in virus movement (Hirashima and Watanabe 2001), and has silencing suppressing activity (Ding et al. 2004; Kubota et al. 2003; Vogler et al. 2007). Lack of MP allows the virus to replicate but it fails to spread cell-to-cell and systemically (Holt and Beachy 1991). The CP is required for encapsidation, stability, and mechanical interplant transmission of the virus. TMV mutants that lack CP fail to move systemically but can still spread cell-to-cell indicating that the virus moves between cells in a nonencapsidated form (Holt and Beachy 1991). The requirement of different sets of viral proteins (and host factors, see, for example, Kim et al. 2007) for local and systemic movement may reflect differences in complexity (i.e., tissuespecific conditions for successful replication, movement, suppression of plant defense responses) between these processes. Whereas systemic movement depends on the ability of the virus to move across several different cell types, including mesophyll, bundle sheath, vascular parenchyma, companion cells, and sieve elements, local cell-to-cell movement involves only epidermal and mesophyll cells. Given the small diameter of the PD pore, viruses utilize diverse mechanisms to modify the structure or SEL of PD. Moreover, apart from the suppression of plant defense responses, viruses rely on specific targeting and transport mechanisms that guide their encapsidated or non-encapsidated genomes from cellular replication sites to and through the channel.

The subsequent paragraphs of this review will attempt to summarize currently known mechanisms involved in PD targeting and PD-mediated cell-to-cell movement of viruses. In addition, the potential role of PD in the cell-tocell movement of silencing signals during viral invasion will be discussed.

\section{Viral strategies for movement through plasmodesmata}

To successfully move through PD, viruses exploit different mechanisms. The two most characterized mechanisms are tubule-guided and non-tubule-guided movement (Fig. 2, Fig. 3 a,b). Examples for viruses employing tubule-guided transport can be found among ssRNA viruses (i.e., como-, nepo-, olea-, alfamo-, bromo-, and trichoviruses; Grieco et al. 1999; Ritzenthaler et al. 1995; van der Wel et al. 1998; van Lent et al. 1991; Wieczorek and Sanfaçon 1993), ssDNA viruses (i.e., tospoviruses; Storms et al. 1995), dsDNA viruses (i.e., caulimoviruses; Kitajima et al. 1969; Perbal et al. 1993), and badnaviruses (Cheng et al. 1998). Tubule-guided transport involves the structural modification of PD by insertion of a tubule assembled by viral MP (Kasteel et al. 1996; Wellink et al. 1993). The desmotubule is absent in these modified PD and in several cases the overall diameter of the PD pore was seen dilated (Kitajima et al. 1969; Kormelink et al. 1994; Linstead et al. 1988; van der Wel et al. 1998).

Examples for viruses employing a non-tubule-guided movement process are tobamo-, diantho-, beny-, tobra-, tombus-, and hordeiviruses. The mechanism of non-tubuleguided movement does not involve major changes in PD structure; nevertheless, the PD in TMV MP-transgenic plants have an increased SEL and contain fibrous material that can be labeled with anti-MP antibodies (Atkins et al. 1991; Ding et al. 1992a). These fibers may be comparable to the tubular arrangement of MP-containing fibers that have been observed to form across intercellular junctions in MPtransgenic cyanobacteria (Heinlein et al. 1998b; Heinlein, 2006). However, whether the fibrous material is involved in increasing the SEL of PD or in viral transport through the pore is not known.

An exciting hypothesis is that viruses may switch their movement strategies depending on host species or environmental parameters. MPs of tubule forming viruses form tubule-like structures when expressed in protoplasts (for examples, see van Lent et al. 1991). Interestingly, seemingly similar structures are formed in TMV-infected protoplasts suggesting that even TMV, the paradigm for 
a

\section{Cell 2}

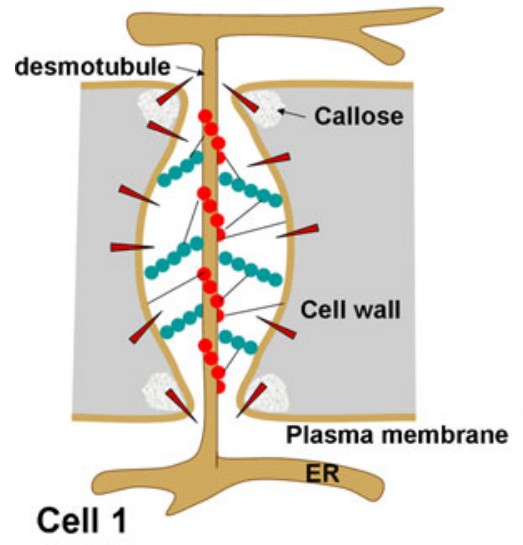

b

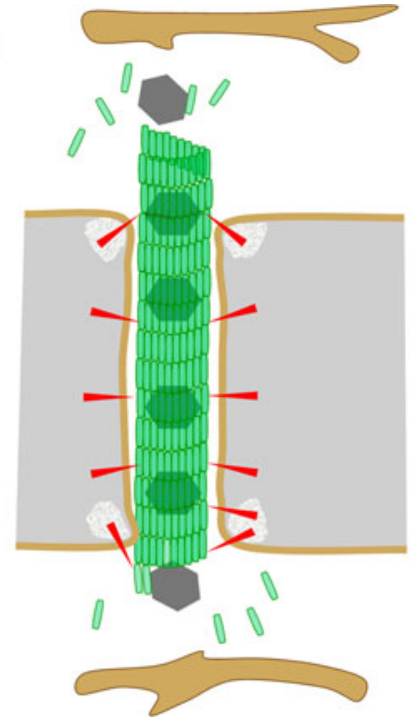

C

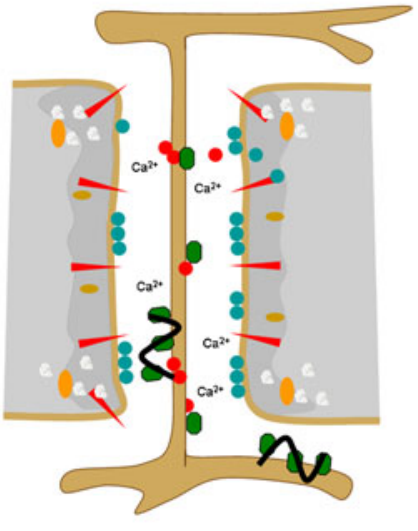

$\searrow$ PDLP

- actin

myosin VIII

- PD protein

beta-glucanase

- Cell wall-modifying enzyme (PME)

TMV MP

GFLVMP

GFLV virion

20 TMV VRNP
Fig. 2 Model for PD modification by tubule-forming and non-tubuleforming MP. a Structure of non-modified PD. b PD modification by GFLV MP. Assembly of GFLV MP into tubules occurs upon interaction of the MP with PDLP. The tubule replaces the desmotubule inside PD. Virions may be transported between cells through polar tubule assembly- and disassembly-driven treadmilling. c In the presence of TMV MP, 1,3- $\beta$-glucanase is delivered to the cell wall

non-tubule-mediated transport of viral ribonucleoprotein complexes (vRNPs), may have the option for different movement strategies (Heinlein et al. 1998a). Common biochemical properties and flexible movement strategies may contribute to the ability of MPs to complement the movement deficiency of unrelated viruses (Lewandowski and Adkins 2005; Morozov et al. 1997; Rao et al. 1998; Sanchez-Navarro et al. 2006; Tamai et al. 2003).

\section{Viral movement proteins}

MPs are classically defined as plant virus-encoded factors that interact with PD to mediate intercellular spread of virus infection. Today, we know that viruses subvert an intercellular communication network for the trafficking of endogenous non-cell-autonomous proteins (NCAPs) and ribonucleoprotein complexes important for developmental and physiological processes (Lucas et al. 2009). Several MPs, in addition, function in the suppression of silencing (Diaz-Pendon and Ding 2008; Ding and Voinnet 2007; Voinnet et al. 2000). Therefore, MPs may be defined as proteins able to facilitate the intercellular trafficking of macromolecules through a variety of cellular functions.

The 30-kDa protein of TMV was the first MP known. Its requirement for cell-to-cell movement was initially demonstrated with temperature-sensitive strains of TMV (Jockusch 1968; Nishiguchi et al. 1978). At permissive temperature $\left(22^{\circ} \mathrm{C}\right)$, these viruses spread normally whereas at non- and degrades callose at the PD neck region, leading to dilation of the PD pore. In addition, ion fluxes across the plasma membrane activate other cell wall-modifying enzymes that reduce the rigidity of the cell wall. Actin severing by MP results in detachment of the structural proteinacious PD components from the desmotubule and relaxation of the plasma membrane. vRNP complexes move through PD by lateral diffusion along the desmotubule

permissive temperature $\left(32^{\circ} \mathrm{C}\right)$, they replicate and assemble normally in leaf cells or protoplasts but cannot move cell-tocell in leaves. The defects were based on amino acid exchange mutations in the $30 \mathrm{kDa}$ protein (MP; Ohno et al. 1983; Zimmern, 1983) and complemented in MP-transgenic plants (Deom et al. 1987; Meshi et al. 1987). Moreover, frame shift mutations in the $30 \mathrm{kDa}$ gene of the virus gave rise to cell-to-cell-movement-defective TMV phenotypes (Holt and Beachy 1991; Meshi et al. 1987). Since then, this protein has been studied in detail and was reported to bind single-stranded nucleic acids (Citovsky et al. 1990), to accumulate in PD and to increase their SEL (Atkins et al. 1991; Ding et al. 1992b; Heinlein et al. 1998a; Moore et al. 1992; Oparka et al. 1997; Tomenius et al. 1987; Wolf et al. 1989), to localize to the ER and cytoskeletal elements (Heinlein et al. 1995; Heinlein et al. 1998a; McLean et al. 1995), and to be phosphorylated by cellular kinases (Citovsky et al. 1993; Haley et al. 1995; Kawakami et al. 2003; Waigmann et al. 2000; Watanabe et al. 1992). The ability of MP to increase PD SEL was demonstrated by the cell-to-cell spread of $10 \mathrm{kDa}$ fluorescence-labeled dextrans upon injection into leaf mesophyll cells of MP-transgenic plants (Wolf et al. 1989) or upon their co-injection with recombinant MP into cells of wild-type plants (Waigmann et al. 1994). Subsequently, the MP was also shown to mediate its own intercellular trafficking (Kotlizky et al. 2001; Waigmann and Zambryski, 1995). Today, we know that most plant viruses encode MPs able to directly or indirectly modify the SEL of PD. 
a

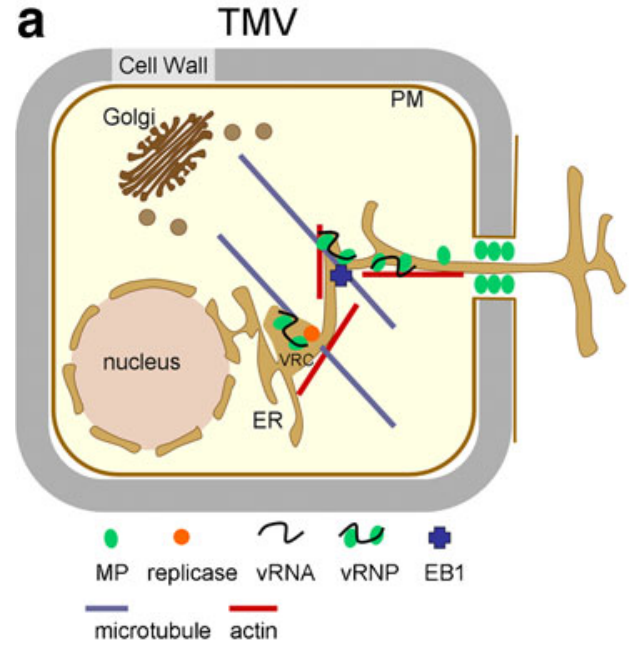

C

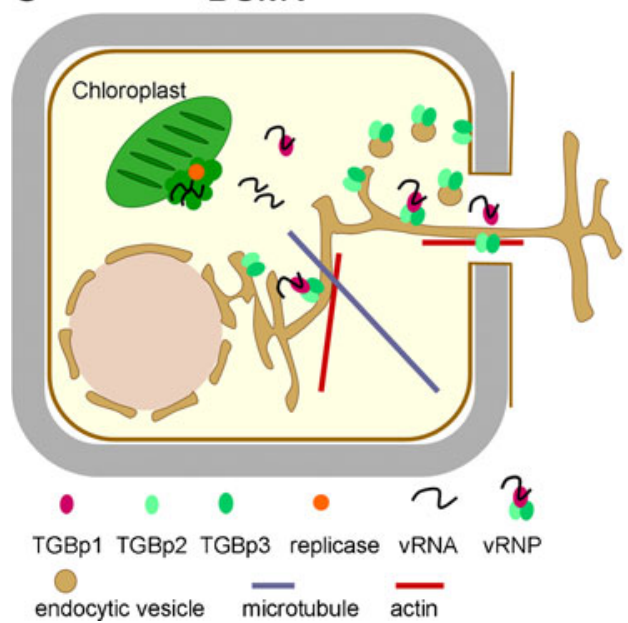

Fig. 3 Model for PD targeting and cell-to-cell transport mechanisms of viruses. a TMV (tobamovirus); vRNP movement. Upon replication at the ER, movement-competent vRNP complexes containing vRNA and MP (potentially also replicase) are released from the viral replication complex (VRC) and move by lateral diffusion along the ER to PD. This diffusive process may be aided by the ER-associated actin network. Microtubules may provide anchorage and assembly sites for VRCs and vRNP complexes. Microtubule end-binding protein 1 (EB1) may assist in attachment and detachment of vRNP complexes on the way to PD. At PD, MP dilates the PD pore by actin severing, callose degradation and induction of ion fluxes to enable diffusion of the vRNP complex through the pore along the desmotubule. b GFLV (nepovirus); tubuleguided virion movement. Upon virus replication on ER membranes, the MP diffuses in the cytoplasm until it finds PDLP, a PD-localized host protein. PDLP is delivered to the plasma membrane through the secretory pathway. PDLP then diffuses along the plasma membrane to reach PD. Virions assembled in the viroplasm may reach PD bound to MP or by free diffusion. Interaction of MP with PDLP at PD induces the formation of tubules within PD. Polar tubule assembly- and disassembly-driven treadmilling of virion-associated MP may cause

Dependent on virus species, intercellular virus movement occurs in virion or non-virion form and often depends on the CP in addition to MP. The MPs of tubule-forming viruses allowing for the movement of virions interact with
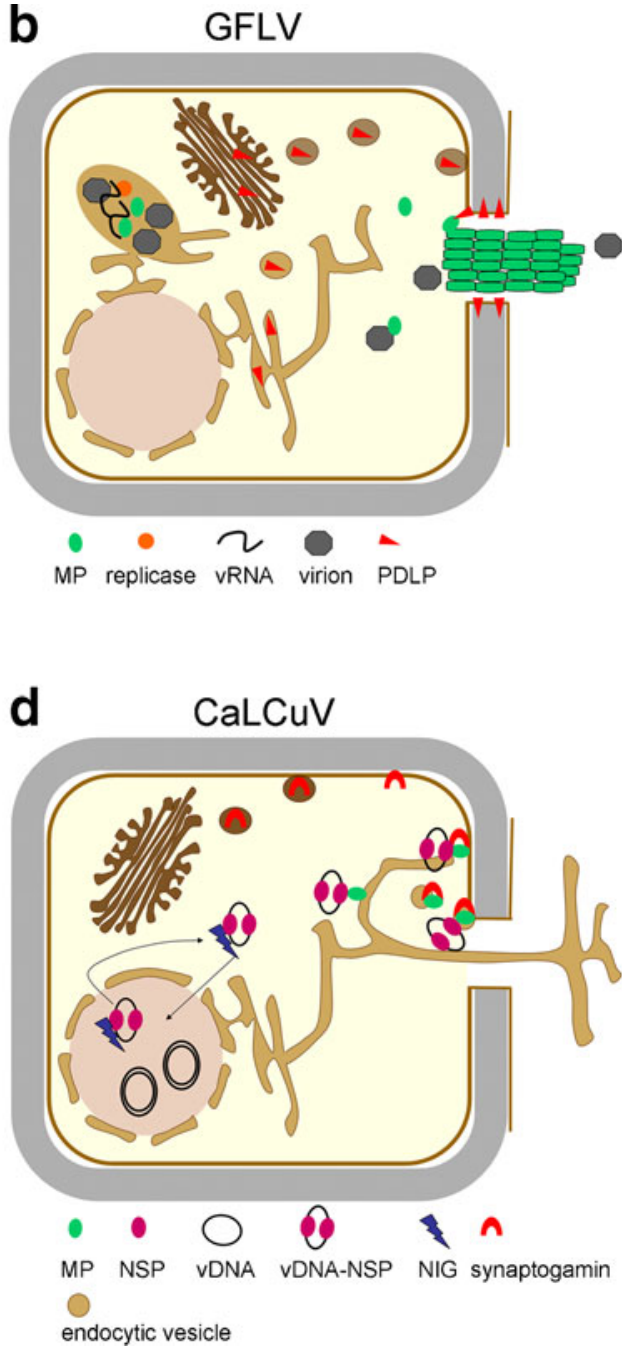

transport of virions through PD. c BSMV (hordeivirus); vRNP movement. After replication on chloroplast membranes, cytosolic TGBp1-RNA complexes associate with membrane-integral TGBp2 and TGBp3 for TGBp3-mediated PD targeting along the ER, which may also be assisted by cytoskeletal elements. At the PD pore, TGBp2 and TGBp3 mediate PD gating through interactions with host receptor proteins and guide the TGBp1-RNA complex through the pore. TGBp2 and TGBp3 may be recycled from the plasma membrane to the ER after passage of the TGBp1-RNA complex through the pore. d CaLCuV (geminivirus), vDNA-protein-complex movement. The nuclear shuttle protein (NSP) shuttles the ssDNA genome into the nucleus for replication and assists in transport of the replicated genome to the cytoplasm for cell-to-cell transport. This process appears to be aided by a plant factor termed NIG (NSP-interacting ATPase). In the cytoplasm, DNA-NSP particles are trapped by MP. Transport to the plasma membrane may occur through diffusion or possibly through association with the ER network. At the plasma membrane, MP interacts with synaptogamin, a secretory cargo protein involved in endocytosis. Synaptogamin mediates delivery of MP or of MP-NSP-ssDNA complexes to PD through a endocytotic-recapture pathway

the $\mathrm{CP}$ of the respective virus, usually at the $\mathrm{C}$-terminus of the MP. The C-terminus of the CPMV MP is located on the inside of the tubule (van Lent et al. 1991), thus in close proximity to the virus particles passing through the tubule. 
Deletion of the C-terminus of this MP interferes with the uptake of virions into the tubule, leading to the observation of "empty" tubules (Lekkerkerker et al. 1996). The MP of CPMV carries determinants for specific recognition and transport of CPMV particles and therefore does not interact with particles of other tested virus species (Carvalho et al. 2003). Specific interactions between tubules and virions mediated by the C-terminal domain of MP have also been observed for Grapevine fanleaf nepovirus (GFLV) and CaMV (Belin et al. 1999; Thomas and Maule 1995).

The bromoviruses BMV and CMV move cell-to-cell as a vRNP and also require CP for spread; however, the CP has auxiliary functions since the viruses can move without $\mathrm{CP}$ if the MP carries specific mutations (Nagano et al. 2001; Sasaki et al. 2005). Thus, it was demonstrated that a deletion in the C-terminus of the CMV MP increased the stability of vRNPs (Andreev et al. 2004; Kim et al. 2004) and allowed CP-independent infection (Nagano et al. 2001). This suggests that a requirement for CP may depend on the affinity of the MP for viral RNA. Thus, strongly RNA binding MPs like the MP of TMV make the CP unnecessary, whereas weakly binding MPs, like the MP of CMV (Li and Palukaitis 1996) necessitate CP, indicating that the RNA needs to be encapsidated in some way for movement (Lucas, 2006). The movement of the icosahedral carmoviruses and the rod-shaped hordeiviruses does not require CP but instead depends on two or three specialized MPs, referred to as double gene block and triple gene block (TGB) proteins, respectively. Current evidence for the role of TGB proteins in cell-to-cell movement of hordei-like viruses (hordei-, pomo-, peclu-, and benyviruses) suggests that viral RNP complexes comprising TGBp1 together with genomic and subgenomic RNA (Lim et al. 2008) are transported to and through PD by the interacting integral membrane proteins TGBp2 and TGBp3, which themselves do not move between cells (Jackson et al. 2009; Morozov and Solovyev 2003) (Fig. 3c). The movement of potexviruses and, presumably, of other viruses with potex-like TGB proteins, depends on the CP in addition to the TGB MPs (Chapman et al. 1992; Foster et al. 1992; Sit and AbouHaidir 1993). However, whether potexviruses move in the form of virions or rather in a non-encapsidated form is unclear. The movement-related vRNPs in potexvirus infections contain TGBp1 that has been suggested to either interact with non-virion complexes that also contain CP (Lough et al. 1998; Lough et al. 2000) or to bind to and modify virions for transport to and through PD (Santa Cruz et al. 1998). Bipartite begomoviruses are DNA viruses that encode two MPs, one (BV1) required for shuttling their DNA genome out of the nucleus (this protein is also referred to as nuclear shuttle protein, NSP) and another (MP or $\mathrm{BC} 1$ ) for targeting their genome to PD (Sanderfoot et al. 1996; Fig. 3d). Whereas the CP is essential for the movement of monopartite begomoviruses (Noris et al. 1998; Rigden et al. 1994; Rojas et al. 2001), the movement of the bipartite viruses is independent of $\mathrm{CP}$ (not in all hosts), indicating that these viruses can effectively move between cells in a non-virion form (Gardiner et al. 1988; Padidam et al. 1995). Microinjection studies established the ability of $\mathrm{BC} 1$ (MP) to move cell-to-cell and to mediate cell-to-cell movement of ss- and ds-DNA. However, the manner in which BV1 might transfer the viral DNA to BC1 for cell-to-cell spread is not yet fully understood (Rojas et al. 2005). The monopartitite begomoviruses lack a Bcomponent encoding $\mathrm{BC} 1$ and $\mathrm{BV} 1$. However, the $\mathrm{CP}$ and the $\mathrm{V} 1$ and/or $\mathrm{C} 4$ proteins have been proposed as functional homologs of $\mathrm{BV} 1$ and $\mathrm{BC} 1$, respectively (Rojas et al. 2001).

Potyviruses represent the largest genus of plant viruses. Microinjection studies performed with proteins encoded by Lettuce mosaic virus and Bean common mosaic necrotic virus established that the $\mathrm{CP}$ and HC-Pro (helper component-protease) provide the classical MP functions for this virus, i.e., these proteins modify PD SEL, move cell-to-cell, and facilitate the movement of vRNA (Rojas et al. 1997). However, mutations in the conserved core region of the TEV CP abolished virion assembly and cell-to-cell movement, suggesting that potyviruses likely move as virions (Dolja et al. 1994; Dolja et al. 1995). The potyvirus CI protein is an RNA helicase essential for virus movement (Carrington et al. 1998) and forms conical deposits at or near PD that may function in the delivery and alignment of an HC-Pro-CP vRNA complex or the filamentous virions to and through PD (Rodríguez-Cerezo et al. 1997; Roberts et al. 1998, 2003). Recent studies indicate that the localization of Turnip mosaic potyvirus CI to PD depends on a newly identified potyviral protein, P3N-PIPO (Wei et al. 2010; Fig. 4a). Umbraviruses like Groundnut rosette virus (GRV) do not encode a CP and thus move cell-to-cell in a nonencapsidated form. Whereas the MP of this virus interacts with PD and facilitates the transport of homologous and heterologous vRNAs through PD, the viral ORF3 protein is required for the formation of RNP particles capable of systemic movement. Particle formation involves interaction of the ORF3 protein with the nucleolar protein fibrillarin. Interestingly, since the virus lacks $\mathrm{CP}$, virion formation and aphid-mediated inter-plant transmission require the $\mathrm{CP}$ of a helper luteovirus. It appears that GRV recruits a nucleolar protein or a helper virus to functionally complement the lack of a CP (Kim et al. 2007). Importantly, GRV illustrates the formation of distinct complexes for either cell-to-cell, systemic, or inter-plant transmission (Fig. 4b). Closteroviruses, such as BYV, have very large RNA genomes and form exceptionally long virions. Their movement involves four structural proteins and one ER-localized MP, which is required for virus movement but is not an integral virion 

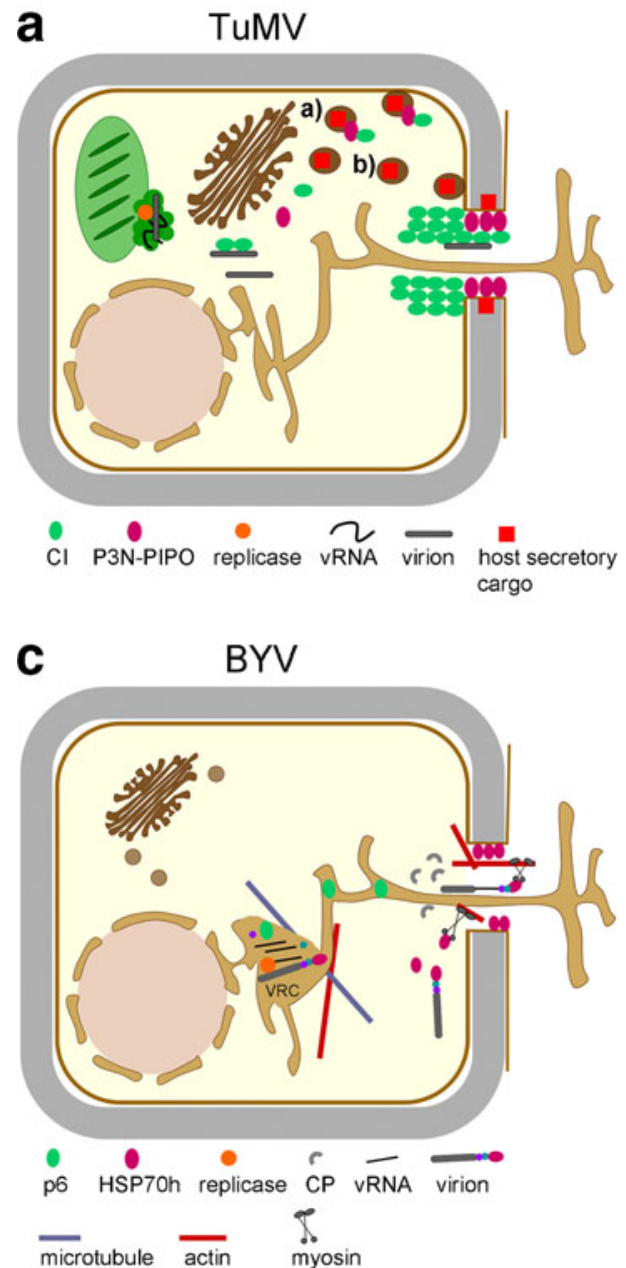

Fig. 4 Model for PD targeting and cell-to-cell transport mechanisms of viruses. a TuMV (potyvirus); virion movement. After replication in the vicinity of chloroplast membranes, virion particles bind the potyvirus MP (CI). Transport to PD is mediated by the virusencoded protein PN3-PIPO. Both MPs, CI and P3N-PIPO, require an intact secretory pethway for PD targeting. As both proteins do not contain a typical transmembrane domain, they may associate with a secretory cargo for transport along the secretory pathway (a), or need a secretory cargo PD-docking molecule (b). In this scenario, virion-CI complexes may find PD-anchored P3N-PIPO by diffusion or bind to $\mathrm{P} 3 \mathrm{~N}-\mathrm{PIPO}$ in the cytosol before reaching the PD pore. At PD, virions are translocated through the pore leaving behind conical CI-containing structures. b GRV (umbravirus); vRNP movement. After replication, probably in association with membranes, MP (ORFp4) binds RNA and localizes to PD. MP-vRNA complexes are sufficient to mediate cell-to-cell spread of the virus. For long distance movement, the ORF3 protein is required. This protein traffics to cajal bodies $(\mathrm{CB})$ and the

component. Three of the four structural components form a narrow tail essential for virion movement (Dolja et al. 2006). One component, the Hsp 70 homolog (HSP70h) localizes to PD in a myosin VIII dependent manner and might be involved in targeting the virion to PD. In addition HSP70h might use its ATPase function for translocating the virus through the pore (Avisar et al. 2008; Fig. 4c).

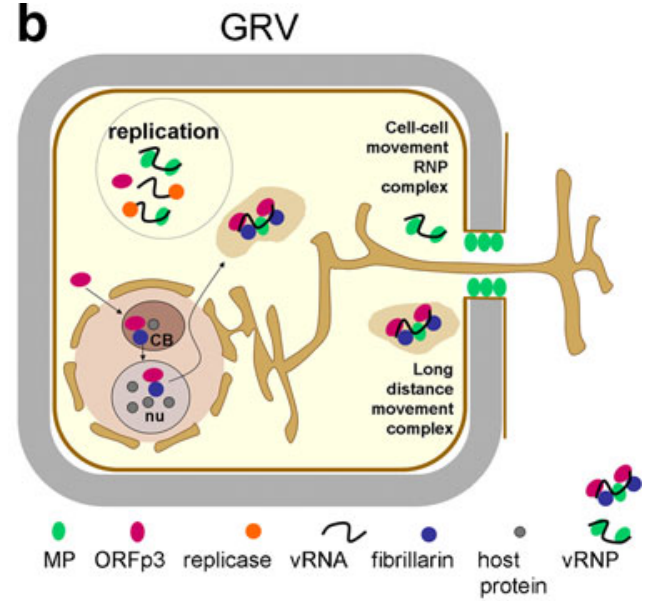

nucleolus (nu), where it recruits a host protein, fibrillarin, to cytosolic inclusion bodies. The cytosoclic inclusion bodies contain vRNP complexes presumably consisting of ORFp3, fibrillarin, vRNA and possibly MP. Since the virus lacks CP, virion formation and inter-plant transmission require the $\mathrm{CP}$ of a helper virus. c BYV (closterovirus); virion movement. BVY replication and virion assembly takes place in ER-containing replication complexes. An ER-localized MP (P6), and four virion-tail structural proteins play a role in virus cell-to-cell transport. How P6 facilitates virus movement is not understood.The virion tail protein $\mathrm{HSP} 70 \mathrm{~h}$ contains ATPase activity and localizes to PD in a actomyosin-dependent manner. The actin network could provide tracks for myosin VIII-mediated trafficking of HSP70h or virions to reach PD; or myosin VIII may provide a PD-docking site for HSP70h or virions diffusing in the cytoplasm. During passage through $\mathrm{PD}, \mathrm{CP}$ is stripped from the virions and RNA is exposed, which allows initiation of replication in the newly infected cell

\section{Molecular mechanism of virus transport through plasmodesmata}

The molecular mechanism by which virus particles or viral RNP complexes are transported through the PD pores into the adjacent cell is unknown. The tubules of tubule-forming viruses extend into the cytoplasm of the adjacent cell with a 
certain length. Although appropriate studies are needed, it appears possible that the tubules may transport virions by a dynamic process similar to microtubule or actin treadmilling, in which monomer assembly at one end of the tubule is balanced by disassembly at the other end. Considering the affinity of the MP for CP and assembled capsids, MPvirion complexes may co-assemble at the tubule base in the infected cell and be transported through PD via tubule treadmilling, and then released in the adjacent cell by disassembly (Fig. 2b). Since tubule formation also occurs on the surface of infected or MP-transfected protoplasts, the process and site of tubule assembly is independent of the presence of a cell wall or PD and likely dependent on a positional mark or receptor at the plasma membrane. Oryzalin treatment of MP-expressing BY-2 cells strongly perturbs this mark and leads to tubule formation at ectopic sites, thus indicating a role of microtubules (MT) in assembly site selection (Laporte et al. 2003). Interestingly, in reports showing tubules (e.g., Storms et al. 1995; van Lent et al. 1991), the tubules are usually shown in association with simple, non-branched PD. Consistently, in MP-expressing BY-2 cell cultures, newly expressed MP was found to assemble into tubules only in primary PD of daughter cell walls and not in the existing PD of the parental walls (Laporte et al. 2003). These findings, together with the fact that tubule-forming viruses can move between tissues originating from different cell lineages, suggest that the viruses move through PD that either remain non-branched or are newly induced. Observations reporting an increase in the number of PD at the leading front of infection of a tubuleforming virus do exist (van der Wel 2000). However, whether tubule formation may indeed be linked to novel channel formation rather than modification of existing nonbranched PD remains to be further established.

The mechanism by which the MPs of non-tubule forming viruses manipulate the SEL of PD is also not known. Since several endogenous plant proteins are able to modify the PD SEL and to move cell-to-cell like MP (Lucas et al. 2009) the MPs likely interact with endogenous mechanisms and host factors for intercellular transport. One hypothesis of how MPs of non-tubule forming viruses may move the viral genome through PD is that MP and other non-cell-autonomous factors may cause a change in local $\mathrm{Ca}^{2+}$ levels, which is known to affect PD SEL and consistent with a calcium-dependent kinase and other calcium-binding proteins associated with PD (Baluska et al. 1999; Baron-Epel et al. 1988; Holdaway-Clarke et al. 2000; Lew 1994; Tucker 1990; Tucker and Boss 1996; Yaholom et al. 1998) (Fig. 2c). MPs could also cause a local depletion of ATP (some MPs were shown to bind nucleotides) also known to cause dilation of PD (Cleland et al. 1994; Tucker, 1993). More recent studies indicate that the MPs of CMV and TMV have F-actin severing activity and that this activity is required to increase PD SEL (Su et al. 2010). These findings are consistent with PD SEL increases in cells treated with cytochalasin D or profilin, which cause actin depolymerization (Ding et al. 1996; White et al. 1994), and with associations of actin and myosin with PD (Blackman and Overall 1998; Faulkner et al. 2009; Golomb et al. 2008; Radford and White 1998; Reichelt et al. 1999; White et al. 1994). MPs may dilate PD also through degradation of callose deposits at PD. Several studies showed a positive correlation of the efficiency of virus spread with the expression level of the callosedegrading enzyme $\beta$-1,3-glucanase (Bucher et al. 2001; Iglesias and Meins 2000). In addition, a PD-associated Arabidopsis $\beta$-1,3-glucanase has recently been isolated and shown to be involved in determining PD SEL (Levy et al. 2007). Importantly, the PVX TGBp2 protein interacts with host proteins that, in turn, interact with $\beta$-1,3-glucanase (Fridborg et al. 2003). Recent studies demonstrate that a stress-induced deposition of PD-associated callose in the presence of a TMV replicon expressing only replicase is lower in TMV MP-expressing plants compared to wild-type plants (Guenoune-Gelbart et al. 2008). The same study also confirmed that ER-membrane-intrinsic proteins can spread cell-to-cell by diffusion and that MP expression hinders movement of ER-membrane-intrinsic probes. By contrast, MP expression potentiates the spread of ER luminal probes. Maximum spread of both types of probes was observed when replicase was expressed in addition to the MP and was suggested to result from prevention of callose deposition at PD by MP and replicase, possibly through recruitment of $\beta$-1,3-glucanase to the pore (GuenouneGelbart et al. 2008; Epel 2009). The results presented by Guenoune-Gelbart et al. (2008) suggest that TMV RNA spreads through PD in the form of a potentially replicaseassociated RNP complex. The movement of the complex would occur by passive diffusion in the lipid milieu of the desmotubular ER and may be driven by a concentration gradient. This model is consistent with previous evidence for a role of replicase in virus movement (Hirashima and Watanabe 2001). The movement-related function of the replicase was mapped to the helicase domain of the protein (Hirashima and Watanabe 2003) and may play a role in unwinding the viral RNA for entering the PD pore. Helicase activity is also an attribute of hordei- and potexvirus TGBp1 proteins (Kalinina et al. 2002; Makarov et al. 2009).

Virus movement through PD may also involve specific chaperones. A role of chaperones in cell-to-cell transport processes is indicated by a study suggesting that transport through PD may involve a degree of protein unfolding (Kragler et al. 1998) and by the observation that cells at the leading front of infection undergo a transient induction of Hsp70 expression (Havelda and Maule 2000; Whitham et 
al. 2003). The closterovirus BYV expresses an Hsp70 homologue required for movement. This protein is thought to facilitate virus movement by binding to a PD receptor as well as to the tail domain of the viral capsid and to translocate the virus through PD by mechanical force (Alzhanova et al. 2001). Finally, MPs may regulate PD SEL by interaction or recruitment of specific cellular receptor proteins. Tobacco NtNCAPP1 interacts with the MP of TMV and also with several other NCAPs. Moreover, the presence of a mutant NtNCAPP1 interfered with the capacity of TMV MP to increase the PD SEL (Lee et al. 2003; Taoka et al. 2007).

\section{Plasmodesmata targeting}

The subcellular mechanisms involved in viral delivery to PD are subject of intense studies. Fluorescent recovery after photobleaching analysis established that molecules as large as $500 \mathrm{kDa}$ can diffuse relatively freely within the cytoplasm (Luby-Phelps 2000; Seksek et al. 1997). Thus, MPs may find PD by diffusion and specific receptormediated docking. Nevertheless, the much larger vRNP complexes and virion particles are presumed to require specific compartmentation and transport mechanisms to ensure coordinated assembly and subsequent delivery to the PD pore (Fig. 3 a,b). For example, specific requirements for the PD targeting of MP and the spread of viral RNP complexes were demonstrated in studies using TMV variants carrying conditional mutations in MP. At nonpermissive conditions the MP was still targeted to PD whereas the virus failed to spread cell-to-cell. Thus, the ability of MP to target PD appears to be required but insufficient for the transport of viral RNA (Boyko et al. 2000a, 2007).

The MPs of several viruses accumulate in secondary PD of mature leaves rather than in primary PD of young leaves (Ding et al. 1992a; Itaya et al. 1998; Vogel et al. 2007). Evidence supporting that this feature may reflect tissue specific functions has been presented for the MP of CMV (Itaya et al. 1998). However, specific accumulation of MP in secondary PD may also occur as a consequence of entrapment of MP in PD in which central cavities have formed. This hypothesis is supported by the observation that a specific mutant MP carrying a single amino acid exchange mutation did not accumulate in PD but retained the ability to spread between cells (Vogler et al. 2008).

Most plant RNA viruses replicate in association with endoplasmic reticulum (ER) membranes. Since the plant ER is highly dynamic (Griffing 2010; Sparkes et al. 2009), allows the trafficking of associated protein complexes by lateral diffusion (Guenoune-Gelbart et al. 2008; Runions et al. 2006), and is continuous between cells through the desmotubule (Ding et al. 1992a), MP and vRNA/virions could reach PD and move cell-to-cell by transport along the membrane. Consistently, the MPs of many plant viruses associate with the ER. TMV MP, for example, localizes to the ER shortly after synthesis (Heinlein et al. 1998a; Sambade et al. 2008). Moreover, the efficiency, by which MP is targeted to PD is reduced if the integrity of the ERactin network is disrupted (Wright et al. 2007). During viral replication, the MP is localized in distinct viral replication complexes (VRCs; Heinlein et al. 1998a; Más and Beachy 1999). These VRCs or VRC sub-complexes may move intracellularly and cell-to-cell in associaton with the ER (Hofmann et al. 2009; Kawakami et al. 2004; Sambade and Heinlein, 2009; Sambade et al. 2008). The ER-associated actin network may facilitate intra- and intercellular trafficking. However, due to tight interaction of the ER with actin filaments (Boevink et al. 1998; Sparkes et al. 2009), the specific roles of ER membrane, actin filaments, and associated myosin motors (Ueda et al. 2010) in the intracellular transport of viral proteins and complexes are not always easy to dissect. Roles of actin and myosins in the trafficking of various viral proteins or in the spread of infection by various viruses have been reported (Avisar et al. 2008; Cotton et al. 2009; Harries et al. 2009a,b; Haupt et al. 2005; Ju et al. 2005; Kawakami et al. 2004; Liu et al. 2005; Prokhnevsky et al. 2005; Vogel et al. 2007). However, further studies are needed to clarify whether trafficking occurs directly via myosin motors along actin filaments or rather through acto-myosin-facilitated trafficking of protein or protein:RNA complexes in the ER. Transport of ER-associated viral complexes may be facilitated by motor proteins either directly, i.e., through specific recognition as myosin cargo, or indirectly, as a consequence of rather general myosin-driven protein bulk flow in the membrane. The immediate mechanism for TMV movement seems not to require an intact actin cytoskeleton since disruption of actin filaments does not inhibit the spread of infection early after treatment (Hofmann et al. 2009). However, since the actin cytoskeleton supports the ER and accelerates lateral diffusion along the ER membrane via ER-associated myosin (Runions et al. 2006; Ueda et al. 2010), the efficiency of vRNP transport (i.e., the number of vRNPs entering the neighboring cell) is likely reduced when actin filaments are disrupted. Longer-term (3 days and more) inhibition of actin filaments or myosins by either longterm silencing or long-term inhibitor treatment indeed reduced the movement efficiency of several viruses tested, including TMV (Harries et al. 2009b). Intriguingly, over-expression of an actin-binding protein strongly and dominantly inhibited TMV movement in an actin-dependent manner, presumably through obstruction of ER-embedded motor trafficking along the filament (Hofmann et al. 2009). Thus, it appears likely that the ER-associated acto-myosin network contributes to 
the efficiency or directionality of ER-mediated MP/viral RNP diffusion.

Although the plant ER is associated with actin and structural associations of ER with MT have only been occasionally described (Franke 1971; McCauley and Hepler 1992), ER motility in Nitella depends on MT (Foissner et al. 2009). Since Charales are considered a sister lineage to land plants (Turmel et al. 2006), this mechanism may also, in parts, be conserved in higher plants. This can be important in the light of the finding that, in addition to associations with the ER, tobamoviral MPs have the capacity to directly interact with MT (Ashby et al. 2006; Boyko et al. 2000a; Ferralli et al. 2006; Heinlein et al. 1995; Padgett et al. 1996). The functional significance of association of TMV MP with MT has long been controversially discussed. Accumulation of TMV MP along MT seen in late infection stages appears not to play a role for virus cell-to-cell movement, as disruption of the MT cytoskeleton by inhibitors and by tubulin silencing did not result in reduced virus movement (Gillespie et al. 2002; Kawakami et al. 2004). In addition, a TMV mutant displaying decreased accumulation of its MP along MT showed increased cell-to-cell movement and decreased degradation compared with the wild-type virus (Gillespie et al. 2002). Thus, MT association of MP may be related to the degradation of the protein at later infection stages (Gillespie et al. 2002; Padgett et al. 1996; Kragler et al. 2003; Curin et al. 2007; Ruggenthaler et al. 2009). Nevertheless, the treatment of plants with MT disrupting agents may not be sufficiently penetrating and effective to interfere with virus movement to an extent required for inhibiting the spread of infection (Seemanpillai et al. 2006). Moreover, whereas ubiquitinylated MP could be detected in infected cells, MT-associated MP isolated from the same cells was found to be free of detectable ubiquitinylation (Ashby et al. 2006). A role of MTs in TMV movement is supported by the observation that optimized temperature conditions allowing for high efficiency TMV movement are correlated with increased MT association of MP near the leading front of infection (Boyko et al. 2000b), and, studies using different stable and conditional MP mutants revealed that the ability of the TMV MP to interact with MT correlates with MP function in virus movement (Boyko et al. 2000a, c; Boyko et al. 2007). Consistently, the efficiency of TMV movement is reduced in tobacco mutants affected in the dynamic behavior of MT (Ouko et al. 2010). MTbinding deficient MP retains the ability to target PD, as has been shown by mutational analysis (Boyko et al. 2000a, c; Boyko et al. 2007). Despite the requirement of further detailed investigation, these findings hint to a specific role of MT in the assembly or transport of the vRNP rather than in the targeting of MP. Cells in the leading front of infection contain ER-associated mobile MP-particles, which occur in the vicinity of MT and display stop-and-go movements dependent on dynamic MT (Boyko et al. 2007; Sambade et al. 2008). These particles may represent early VRCs assembled at ER-MT attachment sites that are released for movement along the ER to reach the PD pore (Hofmann et al. 2007; Kawakami et al. 2004; Sambade et al. 2008) (Fig. 3a). MP also interacts with GFP fusedmicrotubule end-binding protein 1 (EB1), which suggests a role of EB1 in controlling these dynamic movements (Brandner et al. 2008). The formation of MP particles can be reconstituted by transient expression of MP in the absence of infection. This system was used to demonstrate that MP particles are associated with RNA that finally colocalizes with MP in PD (Sambade et al. 2008). Distinct mobile particles were also observed upon injection of infectious and fluorescently labeled TMV RNA into Nicotiana benthamiana trichome cells. The injected RNA initiates infection and associates with ER membrane in a CAP-dependent manner (Christensen et al. 2009). It appears that mobile, ER-associated, vRNP particles may represent a hallmark of early infection stages during which replication sites are established and TMV spreads via the ER-connected PD to non-infected neighboring cells.

Similar to TMV, MPs of TGB-containing viruses such as potex- and hordeiviruses are thought to target $\mathrm{PD}$ via association with the ER (Cowan et al. 2002; Gorshkova et al. 2003; Ju et al. 2005; Krishnamurthy et al. 2003; Solovyev et al. 2000; Tilsner et al. 2010) (Fig. 3c). It is believed that membrane-integral TGBp3 directs the membrane protein TGBp2 and possibly soluble TGBp1-vRNA complexes to the PD pore (Jackson et al. 2009; Morozov and Solovyev 2003; Verchot-Lubicz 2005; Verchot-Lubicz et al. 2007). However, whereas the potexvirus TGBp1 has the ability to target PD, to increase PD SEL, and to move from cell to cell when expressed on its own, the hordei-like TGBp1 depends on TGBp2 and TGBp3 to carry it across PD (Cowan et al. 2002; Erhardt et al. 1999; Erhardt et al. 2000; Lawrence and Jackson, 2001). TGBp2 also induces motile "ER-derived vesicles" (Ju et al. 2005). However, whether these vesicles play a role in the viral movement process remains to be determined. Motile vesicle or granules have also been observed in association with the Potato mop-top pomovirus (PMTV) TGBp2 and TGBp3 proteins. Interestingly, during later stage of infection, the PMTV TGBp2 and TGBp3 occur in association with endocytic vesicles budding from the plasma membrane (Haupt et al. 2005). This observation suggests a role of endosomes in the recycling of TGB proteins upon vRNA delivery to PD (Fig. 3c). Some MPs like the TGBp3 of PMTV or the TGBp3 of Poa semilatent hordeivirus contain a Tyr-based sorting motif also found in KNOLLE and other syntaxins. This motif is recognized by vesicle adapters at the plasma membrane and the ER in animals (Haupt et al. 
2005). Remorin, a protein associated with plasma membrane rafts, interacts with the TGBp1 of PVX and inhibits the spread of the virus upon over-expression. These findings indicate a role of plasma membrane rafts in PD targeting by MPs and presumably other proteins (Raffaele et al. 2009).

In contrast to TMV and TGB-expressing viruses, tubuleforming viruses like GFLV or CPMV seem not to use the ER to target PD. As assembly of the tubule inside the PDpore involves disposal of the desmotubule, and thus ERcontinuity between cells is no longer present, a different mechanism for PD-targeting of tubule-forming viruses appears probable. An alternative pathway for PD targeting is the secretory pathway. Consistently, cell wall targeting and tubule formation by the MP of CPMV are not affected by inhibitors of the cytoskeleton. However, tubule formation, but not cell wall targeting, is disturbed by inhibition of the secretory pathway by Brefeldin A, possibly though interference with the secretory pathway-dependent targeting of a host factor required for tubule formation (Pouwels et al. 2002). Similar results were obtained for the MP of CaMV (Huang et al. 2000) and AMV, although for the latter only a requirement of the intact cytoskeleton has been investigated (Huang et al. 2001a). Studies using MP:GFPtransgenic BY-2 cells demonstrated that the PD targeting of the GFLV MP depends on the secretory pathway and also involves the MT cytoskeleton, whereas actin filaments are dispensable. Upon disruption of MT, MP tubules form at ectopic sites at the cell periphery indicating that MT play a role in providing positional information and in determining $\mathrm{PD}$ as the correct site of tubule assembly (Laporte et al. 2003). The secretory pathway could be required for the intracellular transport and PD targeting of the MP or for the PD targeting of a host factor to which MP binds for tubule assembly at PD. Recent studies indicate that the MP is not a secretory cargo itself but interacts at PD with plasmodesmata-localized proteins (PDLPs), a multigene protein family that localizes to PD via the secretory pathway. Genetic disruption of PDLP expression causes reduced tubule formation, delayed infection, and attenuated symptoms. Apparently, PDLPs act as localized MP-binding proteins that promote virus movement by catalyzing tubule assembly inside PD (Amari et al. 2010; Thomas et al. 2008) (Fig. 3b). Specific sub-cellular localization of MP in advance of tubule formation is also indicated by other studies. For example, studies on CPMV MP expressed in protoplasts indicated that tubule assembly is initiated at distinct punctate localizations of MP at the plasma membrane (Pouwels et al. 2004). Similarly, TMV MP localized at distinct punctae at the plasma membrane in protoplasts (Heinlein et al. 1998a). The nature of these peripheral sites deserves further studies. Are these remnant PD-derived structures left behind upon protoplasting? Do these structures contain PDLPs? And could these structures represent the core structure to which the MPs are targeted before entering PD? Are these structures related to Hechtian attachment sites at which the plasma membrane and the ER are anchored to the cell wall (Oparka 1994; Pont-Lezica et al. 1993)? Plasmolysis of MP-expressing BY-2 cells reveals that PD represent Hechtian attachment sites and that MPs such as those of TMV and GFLV remain in PD or in the associated Hechtian strand upon plasmolysis (Boutant et al. 2009; Laporte et al. 2003). It would be exciting to find PDLPs and other factors as common targets for MPs at peripheral attachment sites and PD.

Indeed, MP-interacting host factors may provide the key to new insights into the mechanisms that allow viruses and their MPs, as well as endogenous non cell-autonomous proteins (NCAPs) and RNA molecules, to interact with cellular pathways for their intra- and intercellular trafficking. The list of identified MP-interacting factors is continuously growing (Table 1). For example, TMV MP interacts with various host factors, including $\alpha, \beta$-tubulin dimers (Ferralli et al. 2006), $\gamma$-tubulin (Sambade et al. 2008), assembled MT (Ashby et al. 2006), GFP-fused Arabidopsis EB1a (Brandner et al. 2008), the MTassociated factor MPB2C (Kragler et al. 2003), and all of these interactions are consistent with a role of MT during infection. Results on interaction of TMV MP with actin are controversial (McLean et al. 1995; Hofmann et al. 2009); however, actin severing by MP could play a role in PD SEL modification ( $\mathrm{Su}$ et al. 2010). Interaction of viral MPs with the cytoskeleton is also indicated by the MP of TSWV that was shown to interact with proteins resembling myosin and kinesin (van Bargen et al. 2001), suggesting that cytoskeleton-mediated transport is essential for the spread of this virus. The increasing number of PD-associated proteins that target $\mathrm{PD}$ in a secretory pathway-dependent manner (Sagi et al. 2005; Thomas et al. 2008) suggests that MPs may have evolved the capacity to interact with various components of the vesicle transport machinery (e.g., Rab proteins) or with vesicle cargo to achieve their own $\mathrm{PD}$ targeting. The interaction of the MP of TMV with the cell wall protein pectin-methylesterase (PME) was proposed to allow MP to target PD via the secretory pathway. However, PD targeting of the TMV MP is independent of the secretory pathway (Amari et al. 2010; Boutant et al. 2009; Tagami and Watanabe 2007) and MP does not colocalize with PME in vivo (Hofmann et al. 2007), which seems to argue against this model. Nevertheless, several other viruses do depend on the secretory pathway. As mentioned above, the MP of GFLV interacts with PDLPs that target PD via the secretory pathway. However, the interaction takes place at PD and the pathway that targets the MP itself to PD is yet unclear (Amari et al. 2010). A role for vesicle trafficking in virus movement is also indicated by the 


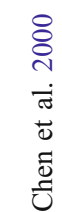

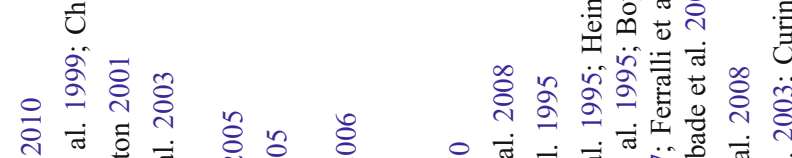

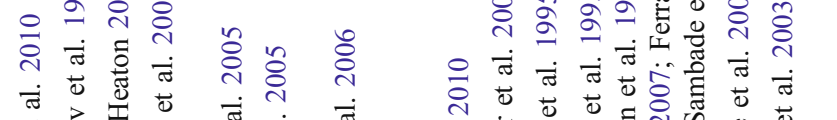

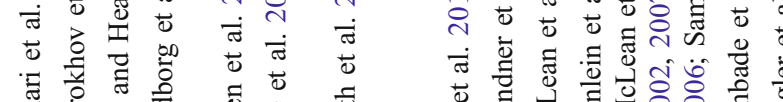

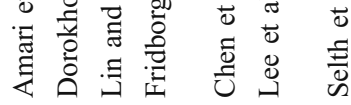

:

总 竞

莺 $\frac{00}{\pi}$

究泀泀

完总

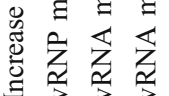

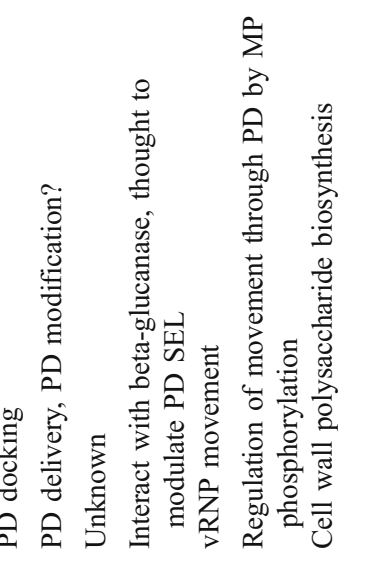

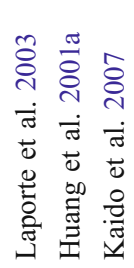

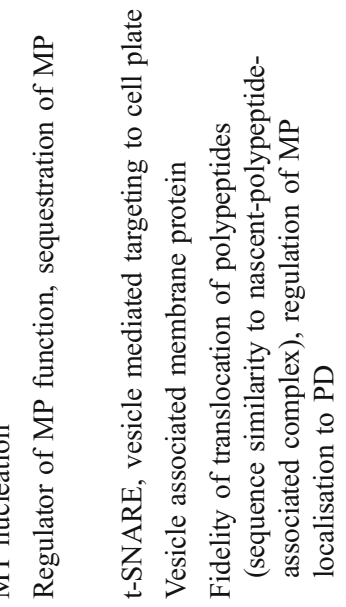

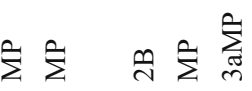

$\hat{\Sigma} \approx \hat{\Sigma} \hat{\Sigma} \quad \hat{\bar{z}} \hat{\Sigma} \hat{\Sigma} \tilde{\Sigma}$

$\sum_{\substack{i \\ j}}^{2}$

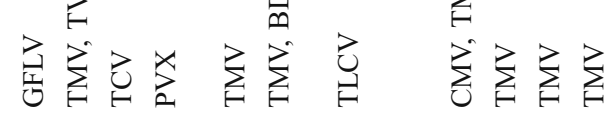

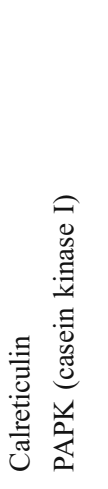

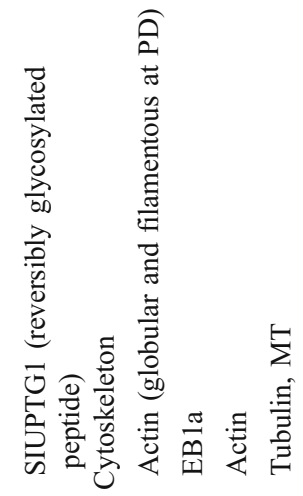

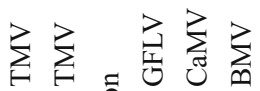

童竞言意

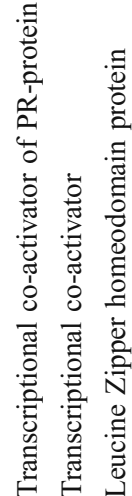

$\sum_{0}^{\infty}$ $2>$ ฮิ

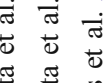

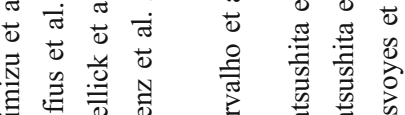

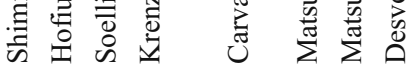

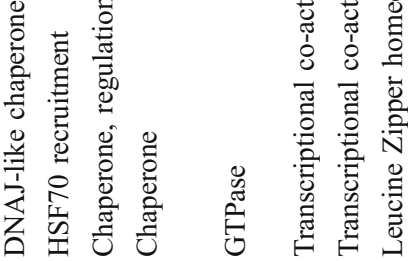




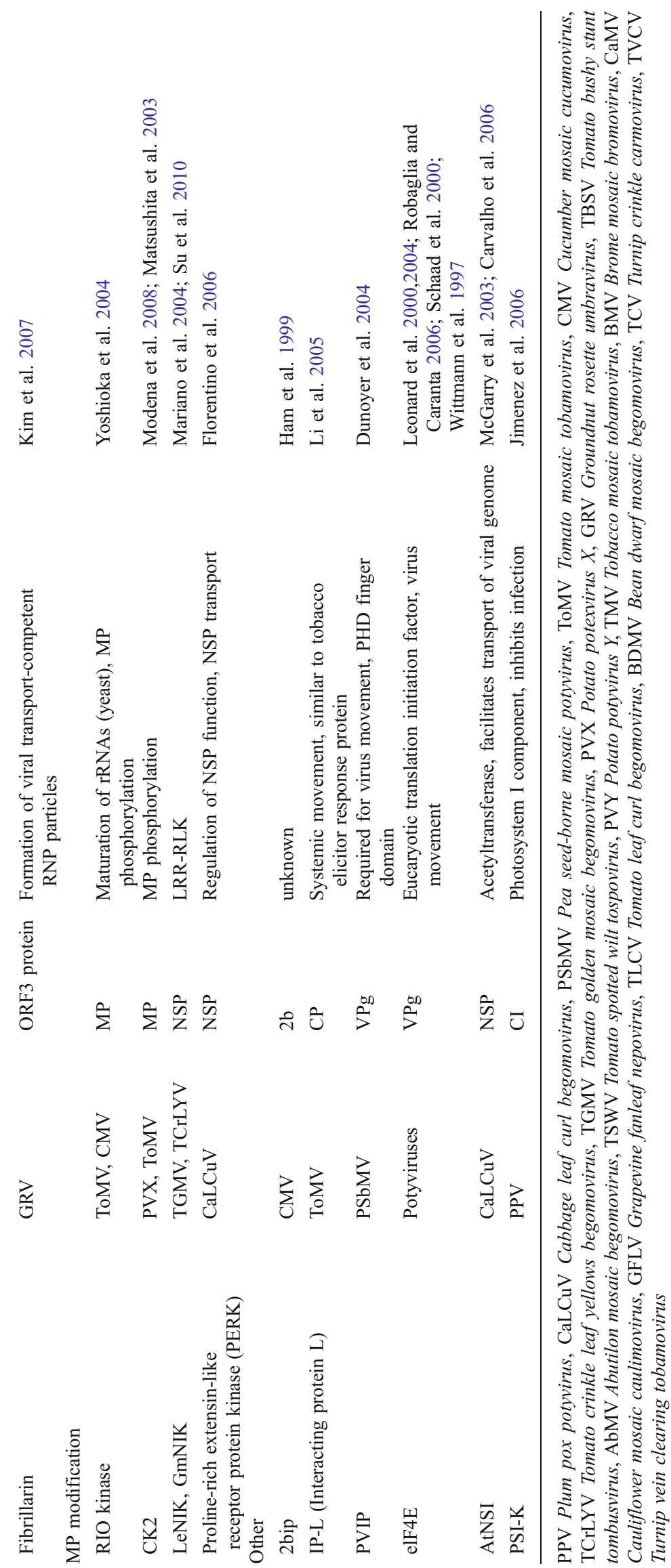


finding that MPs of the begomoviruses Cabagge leaf curl virus and Squash leaf curl virus, and also the MP of TMV, interact with synaptogamin (Lewis and Lazarowitz, 2010), a calcium sensor which regulates endo-and exocytotic processes. In plant mutants deficient of synaptogamin, the cell-to-cell movement of TMV and of these geminiviruses is inhibited, thus supporting an important role of endocytic trafficking in virus movement (Lewis and Lazarowitz 2010). Interactions of MPs with the vesicle trafficking machinery are also indicated by interactions of the GFLV MP with the vesicle syntaxin KNOLLE (Laporte et al. 2003) and of the CaMV MP with a Rab acceptor homolog (Huang et al. 2001b). Moreover, PMTV TGB2 was found to associate with vesicle-like structures and interact with an RME8 homolog, a J-domain protein involved in endocytosis (Haupt et al. 2005). Athough these examples suggest that MPs may directly or indirectly exploit vesicle trafficking to target $\mathrm{PD}$, vesicle trafficking and recycling may also have a role in regulating virus movement. For example, recycling may remove MPs from PD and thus reduce potential cytopathic effects of infection by preventing permanent gating of the pore. Removal of MPs from PD may also represent a mechanism to recycle MPs for participation in additional rounds of transporting viral genomes to PD.

Viruses may also interact with NCAPs to support their own intercellular spread. A first example might be illustrated by the ability of the P22 MP of Tomato bushy stunt tombusvirus to interact with a homeodomain protein (Desvoyes et al. 2002). Since certain homeodomain proteins act non-cell autonomously and move between cells in plants (Lucas et al. 1995; Perbal et al. 1996; RuizMedrano et al. 2004), P22 may represent a first example for MPs which may achieve intercellular transport through interaction with other proteins that by themselves move cell-to-cell. Finally, the p8, one of the two MPs required for the spread of Turnip crinkle carmovirus interacted in vitro and in a yeast two-hybrid system with an Arabidopsis protein containing 'RGD' sequences. RGD sequences are usually carried by extracellular matrix proteins and mediate cellular adhesion through interaction with cellular integrins. Integrin-like proteins and plasma membrane RGD binding sites have been described in plants (Canut et al. 1998; Faik et al. 1998; Laval et al. 1999; Nagpal and Quatrano, 1999; Senchou et al. 2004; Sun et al. 2000). It may be possible that MP interactions with RGD-containing proteins mediate interaction with Hechtian adhesion sites at the plasma membrane. These could represent common acceptor sites for MPs (see above). As already mentioned, MPs appear to interact also with HSF-like chaperones and J-protein cofactors that may assist in the unfolding of viral RNPcomplexes to facilitate their entry into the PD channel (Table 1).

\section{Regulation of virus movement through plasmodesmata}

Probably as a means to minimize the damage to the host by continuous gating of PD, the activity of viral MPs is controlled at several levels. For example, the MP of TMV is only transiently synthesized during early stages of infection (Blum et al. 1989; Watanabe et al. 1984) and degraded by the $26 \mathrm{~S}$ proteasome (Reichel and Beachy 2000). The cessation of MP expression and the degradation of remaining MP leads to the disappearance of the protein several cells behind the leading edge of the infection, giving radially spreading infection sites a ring-shaped pattern if MP is fused to fluorescent proteins (Heinlein et al. 1995; Heinlein et al. 1998a; Hofmann et al. 2009; Padgett et al. 1996; Szécsi et al. 1999). Moreover, the gating of PD in TMV infection is limited to the leading edge even though the PD of cells in the centers of infection sites is still labeled with the MP:GFP (Oparka et al. 1997). This indicates that the MP is rendered nonfunctional for PD gating after the virus has spread. The ability of MP to dilate PD is decreased after phosphorylation (Trutnyeva et al. 2005; Waigmann et al. 2000) by a cell wall-associated kinase (Citovsky et al. 1993). Thus, inactivation of MP function may occur through phosphorylation by a PDlocalized kinase. Association of calcium-dependent or independent MP-phosphorylating protein kinases with cell wall-enriched protein fractions has been reported (Citovsky et al. 1993; Karpova et al. 1997; Lee et al. 2005; Waigmann et al. 2000; Yaholom et al. 1998). A $34 \mathrm{kDa}$ protein belonging to the casein kinase I family was shown to colocalize with MP in PD and to phosphorylate C-terminal residues in MP previously implemented in controlling the PD gating activity of the protein (Lee et al. 2005). Phosphorylation of MP may also serve to stabilize the viral RNP complex during cell-to-cell movement. The MP appears to repress the translation of vRNA in MP-RNA complexes (Karpova et al. 1997). However, when MP is phosphorylated, the vRNA becomes translatable (Karpova et al. 1999). Therefore, phosphorylation of MP during passage of the viral RNP complex through PD may serve as a molecular switch from transport to translation/replication (Rhee et al. 2000). Nevertheless, a recent study indicates that the majority of MP molecules undergo C-terminal phosphorylation on ER membranes before reaching PD (Tyulkina et al. 2010). Several other viral MPs were also shown to become phosphorylated during the infection process or in vitro (Akamatsu et al. 2007; Florentino et al. 2006; Kawakami et al. 1999; Kleinow et al. 2009; Matsushita et al. 2000; Modena et al. 2008; Sokolova et al. 1997; Yoshioka et al. 2004).

Another possibility to control MP activity is its removal from PD. As already mentioned this may occur through endocytic mechanisms (e.g., Haupt et al. 2005). Other 
mechanisms may include sequestration by binding proteins. Overexpression of the MP-interacting factors calreticulin and MPB2C inhibited virus movement (Chen et al. 2005; Kragler et al. 2003). This inhibition was correlated with increased accumulation of MP on MT, which may reflect removal of MP from other sites. Alternatively, overepression of calreticulin or MPB2C may have created a downstream bottleneck in the pathway that targets viral RNPs to PD, thus leading to overaccumulation of MP at upstream sites. The latter hypothesis is consistent with the proposal that MT play a role in the assembly and maturation of vRNP particles (Sambade and Heinlein 2009). With respect to expression of viral proteins it has been demonstrated for hordei-, potex-, and potyviruses that virus movement requires interactions between different movement-related proteins and that virus movement and PD-targeting depends on the expression levels of these proteins relative to each other (Lim et al. 2008, 2009; Tilsner et al. 2010; Wei et al. 2010). Thus, virus movement may be controlled by shifting the balance between movement-associated viral and/or cellular proteins.

\section{The role of RNA silencing in virus movement}

The capacity of a virus to replicate and move throughout the plant depends in part on its ability to suppress antiviral silencing. Silencing is non-cell-autonomous and spreads cell-to-cell through PD by virtue of a sequence-specific silencing signal (Baulcombe 2004). Silenced cells can produce a silencing signal to spread over 10-15 cells. Further spread depends on amplification of the signal in an RDR6-dependent manner (Himber et al. 2003). The exact nature of the silencing signal is not known. However, recent studies have demonstrated that short RNA molecules can spread cell-to-cell and systemically and mediate silencing of target RNAs or methylate target genes in dicer-deficient target tissues (Dunoyer et al. 2010a,b; Molnar et al. 2010). The silencing signal may be linked to an antiviral role of silencing if it moves through the plant either with, or ahead of an invading virus. Thus, virus-derived siRNAs produced by dicer-like enzymes may move into recipient cells, in which they would associate with RNA-induced silencing complexes (RISC) to prime the silencing machinery against the incoming virus (Fig. 5). This way, non-infected cells ahead of the infection front would be immunized to restrict virus spread. Support for this hypothesis proposing antiviral silencing as a major determinant restricting virus movement is based on the notion that several viral suppressors of silencing are also effectors of movement. For instance, silencing suppressors such as the cucumovirus $2 \mathrm{~b}$, potexvirus $\mathrm{P} 25$, potyvirus $\mathrm{HC}-\mathrm{Pro}$, carmovirus $\mathrm{CP}$, hordeivirus $\gamma \mathrm{b}$, sobemovirus $\mathrm{P} 1$, pecluvirus $\mathrm{P} 15$, tombusvirus $\mathrm{P} 19$, and tobamovirus P126/183, all have essential roles in the cellto-cell or long-distance spread of their cognate viruses (Silhavy and Burgyan 2004). A functional link between viral movement and silencing suppression is illustrated by p25 of PVX, which acts as silencing suppressor of the virus (Voinnet et al. 2000) on the one hand and as one of the TGB movement proteins essential for virus movement (TGBp1) on the other (Jackson et al. 2009; VerchotLubicz et al. 2007). Mutational analysis demonstrated that TGBp1 mutants defective in silencing suppression are also non-functional in virus movement; however, mutants functional in silencing suppression but not in movement were also identified. In the case of TMV the replicase promotes virus movement in addition to MP (Hirashima and Watanabe 2001) and provides the silencing suppressor activity of the virus (Csorba et al. 2007; Ding et al. 2004; Kubota et al. 2003; Vogler et al. 2007). A single amino acid exchange mutation in the replicase attenuates silencing suppression, but still allows the virus to replicate and move cell-to-cell (Kubota et al. 2003; Vogler et al. 2007). A subset of the mutations in the replicase of the masked Mstrain of TMV (Holmes, 1934) correlated the attenuation of the silencing suppressing ability of the virus with the weak ability of the virus to move systemically and to cause symptoms (Ding et al. 2004). The same mutations affected accumulation but not the cell-to-cell spread of the virus in the inoculated leaf (Liu et al. 2005). Thus, silencing suppression can be uncoupled from movement, confirming that MPs do not facilitate virus movement exclusively through the suppression of silencing (Bayne et al. 2005; Liu et al. 2005). Nevertheless, the observations clearly indicate that silencing suppression can be important, if not required, for virus movement. Since PVX TGBp1 has the ability to gate PD and to move between cells, this protein could promote virus movement by carrying its silencing suppressing activity into cells ahead of the infection front (VerchotLubicz 2005). A silencing suppressor also able to move between cells and thus to increase the susceptibility of noninfected cells for the incoming virus is the potyvirus HCpro (Kasschau and Carrington 1998; Rojas et al. 1997). In contrast to PVX, in which movement and silencing suppressing functions are combined in one protein (TGBp1/P25; Bayne et al. 2005; Chiu et al. 2010), TMV expresses the MP and in addition, the silencing suppressor containing replicase, which also contributes to virus movement (Hirashima and Watanabe 2001). This difference may reflect varying modes of interactions of the viruses with silencing in order to promote movement. For example, by dividing movement and silencing suppression functions between two proteins these activities can be separately regulated and fine-tuned. Thus, whereas MP acts only in cells at the leading front of infection sites (Oparka et al. 1997), the silencing suppressing activity of the replicase 


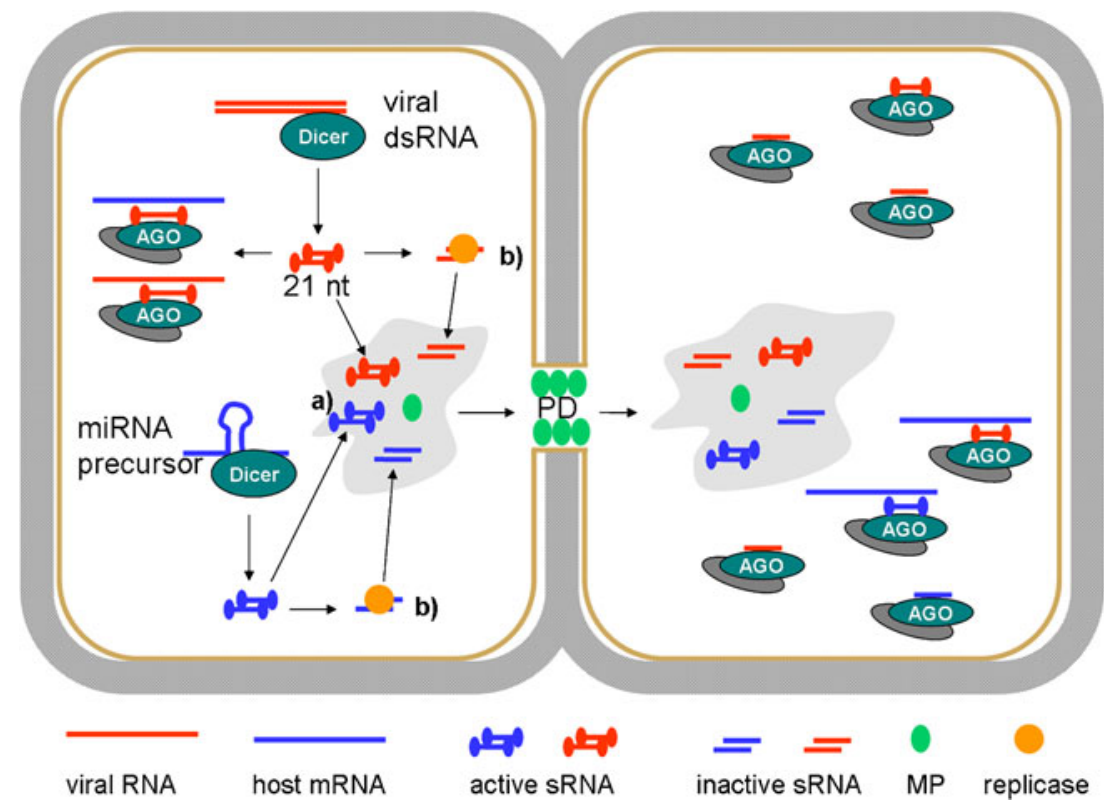

Fig. 5 Impact of RNA silencing and silencing suppression on TMV movement. TMV MP increases PD SEL at the leading front of infection and contributes directly or indirectly to the movement of virus- and host- derived short RNAs (a) into non-infected cells. In non-infected cells, virus-derived short RNAs become incorporated into RISC and prime the plant silencing machinery against the invading virus. In addition, host-derived sRNAs or viral sRNAs with homology to host mRNAs may become similarly incorporated into RISC and hence modulate host gene expression. These processes may serve the plant to limit virus spread and/or help the virus to create an optimal environment for spread in the cell to be infected. TMV replicase binds virus- as well as host-derived short RNAs and inactivates them through binding and sequestration and interference with $3^{\prime}$ methylation (b). Spread of inactivated short RNAs facilitated by MP may lead to incorporation of inactivated sRNAs into RISCs and thus may dampen the activity of the silencing machinery in the cells to be invaded. The extent to which the silencing suppressor deactivates the silencing machinery in the cells ahead of infection may vary depending on the host plant or tissue

RNAs would not be inactivated. Curiously, this is exactly what has been observed (Vogler et al. 2008). However, this proposal of MP being a secondary silencing suppressor requires further experimental support. Alternatively, or in addition, MP may also spread active short RNAs to subvert gene expression in cells to be invaded. The MP may also spread viral siRNAs to attenuate the virus and thus to protect the host against viral over-accumulation (Fig. 5) (Vogler et al. 2008). out that enhancement of silencing spread conferred by MP is simply due to PD gating, the MP may also actively spread small RNAs. This would be consistent with the nonsequence-specific nucleic acid binding activity of MP (Citovsky et al. 1990). Moreover, given that a fraction of the short RNAs produced during TMV infection lack methylation at their $3^{\prime}$ end and appear to be inactive (Csorba et al. 2007; Tagami et al. 2007; Vogler et al. 2007), it may be conceivable that MP spreads suppressorinactivated short RNAs through PD in order to inactivate RISC complexes in cells ahead of the infection front. In this scenario, MP would act as a replicase suppressordependent, secondary silencing suppressor acting at the infection front. Consequently, MP would be expected to enhance antiviral silencing in the absence of the replicaseassociated suppressor, since in this case accumulating short

\section{Outlook}

The movement of plant viruses provides an excellent system to study the role and associated mechanisms of macromolecular trafficking through PD. Similar to viral MPs, a growing number of endogenous proteins has the capacity to alter PD SEL, to spread between cells, and thus to act as non-cell autonomous transcription factor or as a chaperone for RNA transport (Haywood et al. 2002; Lucas and Lee 2004). PD also facilitate the intercellular spread of silencing signals and first attempts are undertaken to address the mechanisms by which these molecules are transported (Dunoyer et al. 2010a,b; Vogler et al. 2008; Yoo 
et al. 2004). The ability of MPs to operate mechanisms for endogenous macromolecular trafficking is supported by the finding that the trafficking of specific MPs and that of specific NCAPs, such as CmPP16, is dominantly inhibited by expression of a mutant NCAP-binding protein, non-cellautonomous pathway protein 1 (NCAPP1; Lee et al. 2003). Common pathways between endogenous and viral macromolecular trafficking are also indicated by the ability of TMV MP-interacting protein MPB2C to also bind to KNOX family members such as Zea mays KNOTTED1 (KN1) and Arabidopsis SHOOTMERISTEMLESS and to interfere with $\mathrm{KN} 1$ cell-to-cell movement upon expression (Winter et al. 2007). It is expected that more interactions between viral components and components of the cell-tocell communication pathway will be found in future, since several labs now engage in the identification of PD structural and regulatory proteins and MP-interacting factors.

As we learn more about the pathways that guide macromolecules to and through PD, we will also gain information why certain proteins and complexes target $\mathrm{PD}$ by selective transport whereas other proteins can find the pore by non-targeted diffusion. Proteins like GFP can spread between cells without specific interactions with cellular components or PD (Crawford and Zambryski 2000) and also some plant transcription factors have this property (Wu et al. 2003). Thus, cell-to-cell movement may occur by default, unless the proteins are associated with other factors, organelles, or other cellular components. ER association of replication or the size of movement complexes may restrict the ability of viruses to reach the PD via diffusion in the cytoplasm but may support PD targeting by diffusion in the ER membrane. Experiments with photo-activatable GFP fusion proteins demonstrated that this PD-connected membrane system exhibits dynamic membrane flow able to transport proteins and protein complexes by diffusion (Runions et al. 2006). Disruption of the associated actomyosin system by treatment with Latrunculin B or truncated myosin XI-K tail expression resulted in altered directionality of the movement, with the protein now diffusing on either site of the photoactivated spot (Sparkes et al. 2009). Consistent with these findings, TMV movement and the PD targeting of its MP continued upon degradation of actin microfilaments (Hofmann et al. 2009; Prokhnevsky et al. 2005; Wright et al. 2007). Thus, TMV movement may occur through ER-mediated diffusion whereby in the presence of a normal actin system this process may be directional and accelerated, $i$. e., with the help of ER-associated myosins (Ueda et al. 2010). ER association of replication and movement may be a means of the virus to enhance the efficiency of PD targeting since diffusion to a particular target like PD occurs more rapidly if it occurs within a $2 \mathrm{D}$ sheet of membrane than within a 3D sphere of cytosplasm. Diffusion is expected to occur even more rapidly along a near-1D ER tubule, e.g., the desmotubule within PD. Viruses that do not utilize the ER (e.g. GFLV, and likely also other tubule-forming viruses) may benefit from cytoplasmic streaming produced by the ER and associated actomyosin activity (Ueda et al. 2010) that may fuel nontargeted diffusion in the cytoplasm.

Nevertheless, although intercellular trafficking may occur mainly by diffusive processes potentially enhanced by actin and myosin, some type of anchorage is expected to orchestrate the controlled assembly of replication factories and movement complexes. Here, direct anchoring interactions with the cytoskeleton could play a role. Accumulations of MP in replication factories and along MT during late infection stages are dispensable for movement (Boyko et al. 2000c; Heinlein et al. 1998a) but may reflect functional associations during earlier stages. As the MP of TMV is post-translationally modified (by e.g., phosphorylation, polyubiquitinylation), it will be important to correlate these modifications with specific associations and functions during the time course of infection.

Future work is needed to dissect the functional relationship between virus movement and RNA silencing responses of the host. Although silencing suppression is not sufficient for movement, efficient movement appears to require silencing suppression (Bayne et al. 2005). Since several viral silencing suppressors have a role in viral movement, silencing suppression may be at the core of the movement process itself. In order to derive from viral studies information of general importance with respect to macromolecular trafficking in plants, it will be necessary to distinguish viral functions involved in plant defense suppression from those directly involved in virus transport.

Acknowledgments AN was supported by HFSPO Research Program Grant 22/2006. We thank Eduardo Peña for providing images of virus infection shown in Fig. 1.

Conflict of Interest The authors declare that they have no conflict of interest.

\section{References}

Akamatsu N, Takeda A, Kishimoto M, Kaido M, Okuno T, Mise K (2007) Phosphorylation and interaction of the movement and coat proteins of Brome mosaic virus in infected barley protoplasts. Arch Virol 152:2087-2093

Alzhanova DV, Napuli AJ, Creamer R, Dolja VV (2001) Cell-to-cell movement and assembly of a plant closterovirus: roles for the capsid proteins and Hsp70 homolog. EMBO J 20:6997-7007

Amari K, Boutant E, Hofmann C, Schmitt-Keichinger C, FernandezCalvino L, Didier P, Lerich A, Mutterer J, Thomas C, Heinlein M, Mely Y, Maule AJ, Ritzenthaler C (2010) A family of 
plasmodesmal proteins with receptor-like properties for plant viral movement proteins. PLoS Pathog 6: e1001119

Andreev IA, Kim HS, Kalinina NO, Rakitina DV, Fitzgerald AG, Palukaitis P, Taliansky ME (2004) Molecular interactions between a plant virus movement protein and RNA: force spectroscopy investigation. J Mol Biol 339:1041-1047

Ashby J, Boutant E, Seemanpillai M, Groner A, Sambade A, Ritzenthaler C, Heinlein M (2006) Tobacco mosaic virus movement protein functions as a structural microtubuleassociated protein. J Virol 80:8329-8344

Atkins D, Hull R, Wells B, Roberts K, Moore P, Beachy RN (1991) The Tobacco mosaic virus $30 \mathrm{~K}$ movement protein in transgenic tobacco plants is localized to plasmodesmata. J Gen Virol 72:209-211

Avisar D, Prokhnevsky AI, Dolja VV (2008) Class VIII myosins are required for plasmodesmatal localization of a closterovirus Hsp70 homolog. J Virol 82:2836-2843

Baluska F, Samaj J, Napier R, Volkmann D (1999) Maize calreticulin localizes preferentially to plasmodesmata in root apex. Plant $\mathrm{J}$ 19:481-488

Baron-Epel O, Hernandez D, Jiang LW, Meiners S, Schindler M (1988) Dynamic continuity of cytoplasmic and membrane compartments between plant cells. J Cell Biol 106:715-721

Baulcombe D (2004) RNA silencing in plants. Nature 431:356-363

Bayne EH, Rakitina DV, Morozov SY, Baulcombe DC (2005) Cell-tocell movement of Potato potexvirus $X$ is dependent on suppression of RNA silencing. Plant J 44:471-482

Belin C, Schmitt C, Gaire F, Walter B, Demangeat G, Pinck L (1999) The nine C-terminal residues of the Grapevine fanleaf nepovirus movement protein are critical for systemic virus spread. J Gen Virol 80:1347-1356

Blackman LM, Overall RL (1998) Immunolocalization of the cytoskeleton to plasmodesmata of Chara corallina. Plant J 14:733-741

Blum H, Gross HJ, Beier H (1989) The expression of the TMVspecific $30-\mathrm{kDa}$ protein in tobacco protoplasts is strongly and selectively enhanced by actinomycin. Virology 169:51-61

Boevink P, Oparka K, Santa Cruz S, Martin B, Betteridge A, Hawes C (1998) Stacks on tracks: the plant Golgi apparatus traffics on an actin/ER network. Plant J 15:441-447

Boutant E, Fitterer C, Ritzenthaler C, Heinlein M (2009) Interaction of the Tobacco mosaic virus movement protein with microtubules during the cell cycle in tobacco BY-2 cells. Protoplasma 237:3-12

Boyko V, Ferralli J, Ashby J, Schellenbaum P, Heinlein M (2000a) Function of microtubules in intercellular transport of plant virus RNA. Nat Cell Biol 2:826-832

Boyko V, Ferralli J, Heinlein M (2000b) Cell-to-cell movement of TMV RNA is temperature-dependent and corresponds to the association of movement protein with microtubules. Plant $\mathrm{J}$ $22: 315-325$

Boyko V, van der Laak J, Ferralli J, Suslova E, Kwon M-O, Heinlein $M$ (2000c) Cellular targets of functional and dysfunctional mutants of Tobacco mosaic virus movement protein fused to GFP. J Virol 74:11339-11346

Boyko V, Ashby JA, Suslova E, Ferralli J, Sterthaus O, Deom CM, Heinlein M (2002) Intramolecular complementing mutations in Tobacco mosaic virus movement protein confirm a role for microtubule association in viral RNA transport. J Virol 76:39743980

Boyko V, Hu Q, Seemanpillai M, Ashby J, Heinlein M (2007) Validation of microtubule-associated Tobacco mosaic virus RNA movement and involvement of microtubule-aligned particle trafficking. Plant J 51:589-603

Brandner K, Sambade A, Boutant E, Didier P, Mély Y, Ritzenthaler C, Heinlein M (2008) TMV movement protein interacts with GFPtagged microtubule endbinding protein 1 (EB1). Plant Physiol $147: 611-623$
Bucher GL, Tarina C, Heinlein M, Di Serio F, Meins F Jr, Iglesias VA (2001) Local expression of enzymatically active class 1 beta-1, 3glucanase enhances symptoms of TMV infection in tobacco. Plant J 28:361-369

Buck KW (1999) Replication of Tobacco mosaic virus RNA. Philos Trans R Soc Lond B Biol Sci 354:613-627

Canut H, Carrasco A, Galaud JP, Cassan C, Bouyssou H, Vita N, Ferrara P, Pont-Lezica R (1998) High affinity RGD-binding sites at the plasma membrane of Arabidopsis thaliana links the cell wall. Plant J 16:63-71

Carrington JC, Jensen PE, Schaad MC (1998) Genetic evidence for an essential role for potyvirus CI protein in cell-to-cell movement. Plant J 14:393-400

Carvalho CM, Wellink J, Ribeiro SG, Goldbach RW, Van Lent JW (2003) The C-terminal region of the movement protein of Cowpea mosaic virus is involved in binding to the large but not to the small coat protein. J Gen Virol 84:2271-2277

Carvalho MF, Turgeon R, Lazarowitz SG (2006) The geminivirus nuclear shuttle protein NSP inhibits the activity of AtNSI, a vascular-expressed Arabidopsis acetyltransferase regulated with the sink-to-source transition. Plant Physiol 140:1317-1330

Carvalho CM, Fontenelle MR, Florentino LH, Santos AA, Zerbini FM, Fontes EP (2008) A novel nucleocytoplasmic traffic GTPase identified as a functional target of the bipartite geminivirus nuclear shuttle protein. Plant J 55:869-880

Chapman SN, Hills G, Watts J, Baulcombe DC (1992) Mutational analysis of the coat protein gene of Potatovirus $X$ : effects on virion morphology and viral pathogenicity. Virology 191:223-230

Chen M-H, Sheng J, Hind G, Handa AK, Citovsky V (2000) Interaction between the Tobacco mosaic virus movement protein and host cell pectin methylesterases is required for viral cell-tocell movement. EMBO J 19:913-920

Chen MH, Tian GW, Gafni Y, Citovsky V (2005) Effects of calreticulin on viral cell-to-cell movement. Plant Physiol 138:1866-1876

Cheng CP, Tzafrir I, Lockhart BE, Olszewski NE (1998) Tubules containing virions are present in plant tissues infected with Commelina yellow mottle badnavirus. J Gen Virol 79:925-929

Chiu MH, Chen IH, Baulcombe DC, Tsai CH (2010) The silencing suppressor P25 of Potato virus $X$ interacts with Argonaute1 and mediates its degradation through the proteasome pathway. Mol Plant Pathol 11:641-649

Christensen N, Tilsner J, Bell K, Hammann P, Parton R, Lacomme C, Oparka K (2009) The 5'cap of Tobacco mosaic virus (TMV) is required for virion attachment to the actin/ER network during early infection. Traffic 10:536-551

Citovsky V, Knorr D, Schuster G, Zambryski P (1990) The P30 movement protein of Tobacco mosaic virus is a single-stranded nucleic acid binding protein. Cell 60:637-647

Citovsky V, McLean BG, Zupan JR, Zambryski P (1993) Phosphorylation of Tobacco mosaic virus cell-to-cell movement protein by a developmentally regulated plant cell wall-associated protein kinase. Genes Dev 7:904-910

Cleland RE, Fujiwara T, Lucas WJ (1994) Plasmodesmal-mediated cell-to-cell transport in wheat roots is modulated by anaerobic stress. Protoplasma 178:81-85

Cotton S, Grangeon R, Thivierge K, Mathieu I, Ide C, Wei T, Wang A, Laliberte JF (2009) Turnip mosaic virus RNA replication complex vesicles are mobile, align with microfilaments, and are each derived from a single viral genome. J Virol 83:10460-10471

Cowan GH, Lioliopoulou F, Ziegler A, Torrance L (2002) Subcellular localization, protein interactions, and RNA binding activity of Potato mop-top virus triple gene block proteins. Virology 298:106-115

Crawford KM, Zambryski PC (2000) Subcellular localization determines the availability of non-targeted proteins to plasmodesmatal transport. Curr Biol 10:1032-1040 
Csorba T, Bovi A, Dalmay T, Burgyan J (2007) The p122 subunit of Tobacco mosaic virus replicase is a potent silencing suppressor and compromises both small interfering RNA- and microRNAmediated pathways. J Virol 81:11768-11780

Curin M, Ojangu EL, Trutnyeva K, Ilau B, Truve E, Waigmann E (2007) MPB2C, a microtubule-associated plant factor, is required for microtubular accumulation of Tobacco mosaic virus movement protein in plants. Plant Physiol 143:801-811

Deom CM, Oliver MJ, Beachy RN (1987) The 30-kilodalton gene product of Tobacco mosaic virus potentiates virus movement. Science 237:384-389

Desvoyes B, Faure-Rabasse S, Chen MH, Park JW, Scholthof HB (2002) A novel plant homeodomain protein interacts in a functionally relevant manner with a virus movement protein. Plant Physiol 129:1521-1532

Diaz-Pendon JA, Ding S-W (2008) Direct and indirect roles of viral suppressors of RNA silencing in pathogenesis. Annu Rev Phytopathol 46:303-326

Ding SW, Voinnet O (2007) Antiviral immunity directed by small RNAs. Cell 130:413-426

Ding B, Haudenshield JS, Hull RJ, Wolf S, Beachy RN, Lucas WJ (1992a) Secondary plasmodesmata are specific sites of localization of the Tobacco mosaic virus movement protein in transgenic tobacco plants. Plant Cell 4:915-928

Ding B, Turgeon R, Parthasarathy MV (1992b) Substructure of freezesubstituted plasmodesmata. Protoplasma 169:28-41

Ding B, Kwon M-O, Warnberg L (1996) Evidence that actin filaments are involved in controlling the permeability of plasmodesmata in tobacco mesophyll. Plant J 10:157-164

Ding XS, Liu J, Cheng NH, Folimonov A, Hou YM, Bao Y, Katagi C, Carter SA, Nelson RS (2004) The Tobacco mosaic virus 126$\mathrm{kDa}$ protein associated with virus replication and movement suppresses RNA silencing. Mol Plant Microbe Interact 17:583592

Dolja VV, Haldeman-Cahill R, Montgomery AE, Vandenbosch KA, Carrington JC (1995) Capsid protein determinants involved in cell-to-cell and long distance movement of Tobacco etch potyvirus. Virology 206:1007-1016

Dolja VV, Haldeman R, Robertson NL, Dougherty WG, Carrington JC (1994) Distinct functions of capsid protein in assembly and movement of Tobacco etch virus. EMBO J 13:1482-1491

Dolja VV, Kreuze JF, Valkonen JPT (2006) Comparative and functional genomics of closteroviruses. Virus Res 117:38-51

Dorokhov YL, Mäkinen K, Yu O, Merits A, Saarinen J, Kalkkinen N, Atabekov JG, Saarma M (1999) A novel function for a ubiquitous plant enzyme pectin methylesterase: the host-cell receptor for the Tobacco mosaic virus movement protein. FEBS Lett 461:223-228

Dunoyer P, Himber C, Voinnet O (2005) DICER-LIKE 4 is required for RNA interference and produces the 21-nucleotide small interfering RNA component of the plant cell-to-cell silencing signal. Nat Genet 37:1356-1360

Dunoyer P, Thomas C, Harrison S, Revers F, Maule A (2004) A cysteine-rich plant protein potentiates potyvirus movement through an interaction with the virus genome-linked protein VPg. J Virol 78:2301-2309

Dunoyer P, Brosnan CA, Schott G, Wang Y, Jay F, Alioua A, Himber C, Voinnet O (2010a) An endogenous, systemic RNAi pathway in plants. EMBO J 29:1699-1712

Dunoyer P, Schott G, Himber C, Meyer D, Takeda A, Carrington JC, Voinnet O (2010b) Small RNA duplexes function as mobile silencing signals between plant cells. Science 328:912-916

Durrant WE, Dong X (2004) Systemic acquired resistance. Annu Rev Phytopathol 42:185-209

Epel BL (2009) Plant viruses spread by diffusion on ER-associated movement-protein-rafts through plasmodesmata gated by viral induced host beta-1,3-glucanases. Semin Cell Dev Biol 20:1074 1081

Erhardt M, Stussi-Garaud C, Guilley H, Richards KE, Jonard G, Bouzoubaa S (1999) The first triple gene block protein of Peanut clump virus localizes to the plasmodesmata during virus infection. Virology 264:220-229

Erhardt M, Morant M, Ritzenthaler C, Stussi-Garaud C, Guilley H, Richards K, Jonard G, Bouzoubaa S, Gilmer D (2000) P42 movement protein of Beet necrotic yellow vein virus is targeted by the movement proteins $\mathrm{P} 13$ and P15 to punctate bodies associated with plasmodesmata. Mol Plant Microbe Interact 13:520-528

Faik A, Laboure AM, Gulino D, Mandaron P, Falconet D (1998) A plant surface protein sharing structural properties with animal integrins. Eur J Biochem 253:552-559

Faulkner CR, Blackman LM, Collings DA, Cordwell SJ, Overall RL (2009) Anti-tropomyosin antibodies co-localise with actin microfilaments and label plasmodesmata. Eur J Cell Biol 88:357-369

Ferralli J, Ashby J, Fasler M, Boyko V, Heinlein M (2006) Disruption of microtubule organization and centrosome function by expression of Tobacco mosaic virus movement protein. J Virol 80:5807-5821

Florentino LH, Santos AA, Fontenelle MR, Pinheiro GL, Zerbini FM, Baracat-Pereira MC, Fontes EP (2006) A PERK-like receptor kinase interacts with the geminivirus nuclear shuttle protein and potentiates viral infection. J Virol 80:6648-6656

Foissner I, Menzel D, Wasteneys GO (2009) Microtubule-dependent motility and orientation of the cortical endoplasmic reticulum in elongating characean internodal cells. Cell Motil Cytoskeleton $66: 142-155$

Foster RLS, Beck DL, Guilford PJ, Voot DM, Van Dolleweerd CJ, Andersen MT (1992) The coat protein of White clover mosaic potexvirus has a role in facilitating cell-to-cell transport in plants. Virology 191:480-484

Franke WW (1971) Cytoplasmic microtubules linked to endoplasmic reticulum with cross-bridges. Exp Cell Res 66:486-489

Fridborg I, Grainger J, Page A, Coleman M, Findlay K, Angell S (2003) TIP, a novel host factor linking callose degradation with the cell-to-cell movement of Potato virus X. Mol Plant Microbe Interact 16:132-140

Gardiner WE, Sunter G, Brand L, Elmer JS, Rogers SG, Bisaro DM (1988) Genetic analysis of Tomato golden mosaic virus: the coat protein is not required for systemic spread or symptom development. EMBO J 7:899-904

Gillespie T, Boevink P, Haupt S, Roberts AG, Toth R, Valentine T, Chapman S, Oparka KJ (2002) Functional analysis of a DNAshuffled movement protein reveals that microtubules are dispensable for the cell-to-cell movement of Tobacco mosaic virus. Plant Cell 14:1207-1222

Golomb L, Abu-Abied M, Belausov E, Sadot E (2008) Different subcellular localizations and functions of Arabidopsis myosin VIII. BMC Plant Biol 8:3

Gorshkova EN, Erokhina TN, Stroganova TA, Yelina NE, AAj Z, Kalinina NO, Schiemann J, Solovyev AG, Morozov SY (2003) Immunodetection and fluorescence microscopy of transgenically expressed hordeivirus TGBp3 movement protein reveals its association with endoplasmic reticulum elements in close proximity to plasmodesmata. J Gen Virol 84:985-994

Grieco F, Castellano MA, Di Sansebastiano GP, Maggipinto G, Neuhaus JM, Martelli GP (1999) Subcellular localization and in vivo identification of the putative movement protein of Olive latent virus 2. J Gen Virol 80:1103-1109

Griffing LR (2010) Networking in the endoplasmic reticulum. Biochem Soc Trans 38:747-753

Guenoune-Gelbart D, Elbaum M, Sagi G, Levy A, Epel BL (2008) Tobacco mosaic virus (TMV) replicase and movement protein function synergistically in facilitating TMV spread by lateral 
diffusion in the plasmodesmal desmotubule of Nicotiana benthamiana. Mol Plant Microbe Interact 21:335-345

Haley A, Hunter T, Kiberstis P, Zimmern D (1995) Multiple serine phosphorylation sites on the $30 \mathrm{kDa}$ TMV cell-to-cell movement protein synthesized in tobacco protoplasts. Plant J 8:715724

Ham B-K, Lee T-H, You JS, Nam Y-W, Kim J-K, Paek K-H (1999) Isolation of a putative tobacco host factor interacting with Cucumber mosaic virus $2 \mathrm{~b}$ protein by yeast two-hybrid screening. Mol Cells 9:548-555

Harries PA, Palanichelvam K, Yu W, Schoelz JE, Nelson RS (2009a) The Cauliflower mosaic virus protein P6 forms motile inclusions that traffic along actin microfilaments and stabilize microtubules. Plant Physiol 149:1005-1016

Harries PA, Park JW, Sasaki N, Ballard KD, Maule AJ, Nelson RS (2009b) Differing requirements for actin and myosin by plant viruses for sustained intercellular movement. Proc Natl Acad Sci USA 106:17594-17599

Haupt S, Cowan GH, Ziegler A, Roberts AG, Oparka KJ, Torrance L (2005) Two plant-viral movement proteins traffic in the endocytic recycling pathway. Plant Cell 17:164-181

Havelda Z, Maule AJ (2000) Complex spatial responses to Cucumber mosaic virus infection in susceptible Cucurbita pepo cotyledons. Plant Cell 12:1975-1985

Haywood V, Kragler F, Lucas WJ (2002) Plasmodesmata: pathways for protein and ribonucleoprotein signaling. Plant Cell Supplement: S303-S325

Heinlein M (2002a) Plasmodesmata: dynamic regulation and role in macromolecular cell-to-cell signalling. Curr Opin Plant Biol 5:543-552

Heinlein M (2002b) The spread of Tobacco mosaic virus infection: insights into the cellular mechanism of RNA transport. Cell Mol Life Sci 59:58-82

Heinlein M (2005) Systemic RNA silencing. In: Oparka K (ed) Plasmodesmata, vol 18. Blackwell, Oxford, pp 212-240

Heinlein M (2006) TMV movement protein targets cell-cell channels in plants and prokaryotes: possible roles of tubulin- and FtsZbased cytoskeletons. In F Baluska, D Volkmann, PW Barlow, eds, Cell-cell channels. Landes Bioscience, pp 176-182

Heinlein M, Epel BL (2004) Macromolecular transport and signaling through plasmodesmata. Int Rev Cytol 235:93-164

Heinlein M, Epel BL, Padgett HS, Beachy RN (1995) Interaction of tobamovirus movement proteins with the plant cytoskeleton. Science 270:1983-1985

Heinlein M, Padgett HS, Gens JS, Pickard BG, Casper SJ, Epel BL, Beachy RN (1998a) Changing patterns of localization of the Tobacco mosaic virus movement protein and replicase to the endoplasmic reticulum and microtubules during infection. Plant Cell 10:1107-1120

Heinlein M, Wood MR, Thiel T, Beachy RN (1998b) Targeting and modification of prokaryotic cell-cell junctions by Tobacco mosaic virus cell-to-cell movement protein. Plant J 14:345-351

Himber C, Dunoyer P, Moissiard G, Ritzenthaler C, Voinnet O (2003) Transitivity-dependent and -independent cell-to-cell movement of RNA silencing. EMBO J 22:4523-4533

Hirashima K, Watanabe Y (2001) Tobamovirus replicase coding region is involved in cell-to-cell movement. J Virol 75:88318836

Hirashima K, Watanabe Y (2003) RNA helicase domain of tobamovirus replicase executes cell-to-cell movement possibly through collaboration with its nonconserved region. J Virol 77:1235712362

Hofius D, Maier AT, Dietrich C, Jungkunz I, Bornke F, Maiss E, Sonnewald U (2007) Capsid protein-mediated recruitment of host DnaJ-like proteins is required for Potato virus $Y$ infection in tobacco plants. J Virol 81:11870-11880
Hofmann C, Sambade A, Heinlein M (2007) Plasmodesmata and intercellular transport of viral RNA. Biochem Soc Trans 35:142145

Hofmann C, Niehl A, Sambade A, Steinmetz A, Heinlein M (2009) Inhibition of TMV movement by expression of an actin-binding protein. Plant Physiol 149:1810-1823

Holdaway-Clarke TL, Walker NA, Hepler PK, Overall RL (2000) Physiological elevations in cytoplasmic free calcium by cold or ion injection result in transient closure of higher plant plasmodesmata. Planta 210:329-335

Holmes FO (1934) A masked strain of Tobacco mosaic virus. Phytopathology 24:845-873

Holt CA, Beachy RN (1991) In vivo complementation of infectious transcripts from mutant Tobacco mosaic virus cDNAs in transgenic plants. Virology 181:109-117

Huang Z, Han Y, Howell SH (2000) Formation of surface tubules and fluorescent foci in Arabidopsis thaliana protoplasts expressing a fusion between the green fluorescent protein and the Cauliflower mosaic virus movement protein. Virology 271:58-64

Huang M, Jongejan L, Zheng H, Zhang L, Bol JF (2001a) Intracellular localization and movement phenotypes of Alfalfa mosaic virus movement protein mutants. Mol Plant Microbe Interact 14:10631074

Huang Z, Andianov VM, Han Y, Howell SH (2001b) Identification of Arabidopsis proteins that interact with the Cauliflower mosaic virus (CaMV) movement protein. Plant Mol Biol 47:663-675

Huang T, Bohlenius H, Eriksson S, Parcy F, Nilsson O (2005) The mRNA of the Arabidopsis gene FT moves from leaf to shoot apex and induces flowering. Science 309:1694-1696

Iglesias VA, Meins F Jr (2000) Movement of plant viruses is delayed in a $\beta$-1,3-glucanase-deficient mutant showing a reduced plasmodesmatal size exclusion limit and enhanced callose deposition. Plant J 21:157-166

Ishiwatari Y, Fujiwara T, McFarland KC, Nemoto K, Hayashi H, Chino M, Lucas WJ (1998) Rice phloem thioredoxin h has the capacity to mediate its own cell-to-cell transport through plasmodesmata. Planta 205:12-22

Itaya A, Woo YM, Masuta C, Bao Y, Nelson RS, Ding B (1998) Developmental regulation of intercellular protein trafficking through plasmodesmata in tobacco leaf epidermis. Plant Physiol 118:373-385

Jackson AO, Lim HS, Bragg J, Ganesan U, Lee MY (2009) Hordeivirus replication, movement, and pathogenesis. Annu Rev Phytopathol 47:385-422

Jimenez I, Lopez L, Alamillo JM, Valli A, Garcia JA (2006) Identification of a Plum pox virus CI-interacting protein from chloroplast that has a negative effect in virus infection. Mol Plant Microbe Interact 19:350-358

Jockusch H (1968) Two mutants of Tobacco mosaic virus temperaturesensitive in two different functions. Virology 35:94-101

Ju HJ, Samuels TD, Wang YS, Blancaflor E, Payton M, Mitra R, Krishnamurthy K, Nelson RS, Verchot-Lubicz J (2005) The Potato virus $X$ TGBp2 movement protein associates with endoplasmic reticulum-derived vesicles during virus infection. Plant Physiol 138:1877-1895

Kaido M, Inoue Y, Takeda Y, Sugiyama K, Takeda A, Mori M, Tamai A, Meshi T, Okuno T, Mise K (2007) Downregulation of the NbNACal gene encoding a movement-protein-interacting protein reduces cell-to-cell movement of Brome mosaic virus in Nicotiana benthamiana. Mol Plant Microbe Interact 20:671-681

Karpova OV, Ivanov KI, Rodionova P, Dorokhov YL, Atabekov JG (1997) Nontranslatability and dissimilar behavior in plants and protoplasts of viral RNA and movement protein complexes formed in vitro. Virology 230:11-21

Kalinina NO, Rakitina DA, Solovyev AG, Schiemann J, Morozov SY (2002) RNA helicase activity of the plant virus movement 
proteins encoded by the first gene of the triple gene block. Virology 296:321-329

Karpova OV, Rodionova NP, Ivanov KI, Kozlovsky SV, Dorokhov YL, Atabekov JG (1999) Phosphorylation of Tobacco mosaic virus movement protein abolishes its translation repressing ability. Virology 261:20-24

Kasschau KD, Carrington JC (1998) A counterdefensive strategy of plant viruses: suppression of posttranscriptional gene silencing. Cell 95:461-470

Kasteel DTJ, Perbal M-C, Boyer J-C, Wellink J, Goldbach RW, Maule AJ, van Lent JWM (1996) The movement proteins of Cowpea mosaic virus and Cauliflower mosaic virus induce tubular structures in plant and insect cells. J Gen Virol 77:2857-2864

Kawakami S, Padgett HS, Hosokawa D, Okada Y, Beachy RN, Watanabe Y (1999) Phosphorylation and/or presence of serine 37 in the movement protein of Tomato mosaic tobamovirus is essential for intracellular localization and stability in vivo. J Virol 73:6831-6840

Kawakami S, Hori K, Hosokawa D, Okada Y, Watanabe Y (2003) Defective tobamovirus movement protein lacking wild-type phosphorylation sites can be complemented by substitutions found in revertants. J Virol 77:1452-1461

Kawakami S, Watanabe Y, Beachy RN (2004) Tobacco mosaic virus infection spreads cell to cell as intact replication complexes. Proc Natl Acad Sci USA 101:6291-6296

Kehr J, Buhtz A (2008) Long distance transport and movement of RNA through the phloem. J Exp Bot 59:85-92

Kim SH, Kalinina NO, Andreev I, Ryobov EV, Fitzgerald AG, Taliansky ME, Paukaitis P (2004) The C-terminal 33 amino acids of the Cucumber mosaic virus 3 a protein affect virus movement, RNA binding and inhibition of infection and translation. J Gen Virol 85:221-230

Kim JY (2005) Regulation of short-distance transport of RNA and protein. Curr Opin Plant Biol 8:45-52

Kim SH, MacFarlane S, Kalinina NO, Rakitina DV, Ryabov EV, Gillespie T, Haupt S, Brown JW, Taliansky M (2007) Interaction of a plant virus-encoded protein with the major nucleolar protein fibrillarin is required for systemic virus infection. Proc Natl Acad Sci USA 104:11115-11120

Kitajima EW, Lauritis JA, Swift H (1969) Fine structure of zinnial leaf tissues infected with Dahlia mosaic virus. Virology 39:240-249

Kleinow T, Nischang M, Beck A, Kratzer U, Tanwir F, Preiss W, Kepp G, Jeske H (2009) Three C-terminal phosphorylation sites in the Abutilon mosaic virus movement protein affect symptom development and viral DNA accumulation. Virology 390:89-101

Kormelink R, Storms M, Van Lent J, Peters D, Goldbach R (1994) Expression and subcellular location of the NSM protein of Tomato spotted wilt virus (TSWV), a putative viral movement protein. Virology 200:56-65

Kotlizky G, Katz A, van der Laak J, Boyko V, Lapidot M, Beachy RN, Heinlein M, Epel BL (2001) A dysfunctional movement protein of Tobacco mosaic virus interferes with targeting of wild type movement protein to microtubules. Mol Plant Microbe Interact 7:895-904

Kragler F, Monzer J, Shash K, Xoconoctle-Cazares B, Lucas WJ (1998) Cell-to-cell transport of proteins: requirement for unfolding and characterization of binding to a putative plasmodesmal receptor. Plant J 15:367-381

Kragler F, Curin M, Trutnyeva K, Gansch A, Waigmann E (2003) MPB2C, a microtubule-associated plant protein binds to and interferes with cell-to-cell transport of Tobacco mosaic virus movement protein. Plant Physiol 132:1870-1883

Krenz B, Windeisen V, Wege C, Jeske H, Kleinow T (2010) A plastid-targeted heat shock cognate $70 \mathrm{kDa}$ protein interacts with the Abutilon mosaic virus movement protein. Virology 401:6-17
Krishnamurthy K, Heppler M, Mitra R, Blancaflor E, Payton M, Nelson RS, Verchot-Lubicz J (2003) The Potato virus $X$ TGBp3 protein associates with the ER network for virus cell-to-cell movement. Virology 309:135-151

Kubota K, Tsuda S, Tamai A, Meshi T (2003) Tomato mosaic virus replication protein suppresses virus-targeted posttranscriptional gene silencing. J Virol 77:11016-11026

Kurata T, Ishida T, Kawabata-Awai C, Noguchi M, Hattori S, Sano R, Nagasaka R, Tominaga R, Koshino-Kimura Y, Kato T, Sato S, Tabata S, Okada K, Wada T (2005) Cell-to-cell movement of the CAPRICE protein in Arabidopsis root epidermal cell differentiation. Development 132:5387-5398

Laporte C, Vetter G, Loudes AM, Robinson DG, Hillmer S, StussiGaraud C, Ritzenthaler C (2003) Involvement of the secretory pathway and the cytoskeleton in intracellular targeting and tubule assembly of Grapevine fanleaf virus movement protein in tobacco BY-2 cells. Plant Cell 15:2058-2075

Laval V, Chabannes M, Carriere M, Canut H, Barre A, Rouge P, PontLezica R, Galaud J (1999) A family of Arabidopsis plasma membrane receptors presenting animal beta-integrin domains. Biochim Biophys Acta 1435:61-70

Lawrence DM, Jackson AO (2001) Interactions of the TGB1 protein during cell-to-cell movement of Barley stripe mosaic virus. J Virol 75:8712-8723

Lee JY, Taoka K, Yoo BC, Ben-Nissan G, Kim DJ, Lucas WJ (2005) Plasmodesmal-associated protein kinase in tobacco and Arabidopsis recognizes a subset of non-cell-autonomous proteins. Plant Cell 17:2817-2831

Lee J-Y, Yoo B-C, Rojas MR, Gomez-Ospina N, Staehelin LA, Lucas WJ (2003) Selective trafficking of non-cell-autonomous proteins mediated by NtNCAPP1. Science 299:392-396

Lekkerkerker A, Wellink J, Yuan P, van Lent J, Goldbach R, van Kammen AB (1996) Distinct functional domains in the Cowpea mosaic virus movement protein. J Virol 70:5658-5661

Leonard S, Plante D, Wittmann S, Daigneault N, Fortin MG, Laliberte JF (2000) Complex formation between potyvirus VPg and translation eukaryotic initiation factor $4 \mathrm{E}$ correlates with virus infectivity. J Virol 74:7730-7737

Leonard S, Viel C, Beauchemin C, Daigneault N, Fortin MG, Laliberte JF (2004) Interaction of VPg-Pro of Turnip mosaic virus with the translation initiation factor $4 \mathrm{E}$ and the poly(A)binding protein in planta. J Gen Virol 85:1055-1063

Levy A, Erlanger M, Rosenthal M, Epel BL (2007) A plasmodesmataassociated beta-1, 3-glucanase in Arabidopsis. Plant J 49:669682

Lew RR (1994) Regulation of electrical coupling between Arabidopsis root hairs. Planta 193:67-73

Lewandowski DJ, Adkins S (2005) The tubule-forming NSm protein from Tomato spotted wilt virus complements cell-to-cell and long-distance movement of Tobacco mosaic virus hybrids. Virology 342:26-37

Lewis JD, Lazarowitz SG (2010) Arabidopsis synaptotagmin SYTA regulates endocytosis and virus movement protein cell-to-cell transport. Proc Natl Acad Sci USA 107:2491-2496

Li Q, Palukaitis P (1996) Comparison of the nucleic acid- and NTPbinding properties of the movement protein of Cucumber mosaic cucumovirus and Tobacco mosaic tobamovirus. Virology 216:71-79

Li Y, Wu MY, Song HH, Hu X, Qiu BS (2005) Identification of a tobacco protein interacting with Tomato mosaic virus coat protein and facilitating long-distance movement of virus. Arch Virol 150:1993-2008

Lim HS, Bragg JN, Ganesan U, Lawrence DM, Yu J, Isogai M, Hammond J, Jackson AO (2008) Triple gene block protein interactions involved in movement of Barley stripe mosaic virus. J Virol 82:4991-5006 
Lim HS, Bragg JN, Ganesan U, Ruzin S, Schichnes D, Lee MY, Vaira AM, Ryu KH, Hammond J, Jackson AO (2009) Subcellular localization of the Barley stripe mosaic virus triple gene block proteins. J Virol 83:9432-9448

Lin B, Heaton LA (2001) An Arabidopsis thaliana protein interacts with a movement protein of Turnip crinkle virus in yeast cells and in vitro. J Gen Virol 82:1245-1251

Linstead PJ, Hills GJ, Plaskitt KA, Wilson IG, Harker CI, Maule AJ (1988) The subcellular location of the gene I product of Cauliflower mosaic virus is consistent with a function associated with virus spread. J Gen Virol 69:1809-1818

Liu J-Z, Blancaflor EB, Nelson RS (2005) The Tobacco mosaic virus 126-kilodalton protein, a constituent of the virus replication complex, alone or within the complex aligns with and traffics along microfilaments. Plant Physiol 138:1877-1895

Lough TJ, Shash K, Xoconostle-Cazares B, Hofstra KR, Beck DL, Balmori E, Forster RL, Lucas WJ (1998) Molecular dissection of the mechanism by which potexvirus triple gene block proteins mediate cell-to-cell transport of infectious RNA. Mol Plant Microbe Interact 11:801-814

Lough TJ, Netzler NE, Emerson SJ, Sutherland P, Carr F, Beck DL, Lucas WJ, Forster RL (2000) Cell-to-cell movement of potexviruses: evidence for a ribonucleoprotein complex involving the coat protein and first triple gene block protein. Mol Plant Microbe Interact 13:962-974

Luby-Phelps K (2000) Cytoarchitecture and physical properties of cytoplasm: volume, viscosity, diffusion, intracellular surface area. Int Rev Cytol 192:189-221

Lucas WJ (2006) Plant viral movement proteins: agents for cell-to-cell trafficking of viral genomes. Virology 344:169-184

Lucas WJ, Lee JY (2004) Plasmodesmata as a supracellular control network in plants. Nat Rev Mol Cell Biol 5:712-726

Lucas WJ, Bouche-Pillon S, Jackson DP, Nguyen L, Baker L, Ding B, Hake S (1995) Selective trafficking of KNOTTED1 homeodomain protein and its RNA through plasmodesmata. Science 270:1980-1983

Lucas WJ, Yoo B-C, Kragler F (2001) RNA as a long-distance information macromolecule in plants. Nat Rev Mol Cell Biol 2:849-857

Lucas WJ, Ham BK, Kim JY (2009) Plasmodesmata - bridging the gap between neighboring plant cells. Trends Cell Biol 19:495503

Makarov VV, Rybakova EN, Efimov AV, Dobrov EN, Serebryakova MV, Solovyev AG, Yaminsky IV, Taliansky ME, Morozov SY, Kalinina NO (2009) Domain organization of the N-terminal portion of hordeivirus movement protein TGBp1. J Gen Virol 90:3022-3032

Mariano AC, Andrade MO, Santos AA, Carolino SM, Oliveira ML, Baracat-Pereira MC, Brommonshenkel SH, Fontes EP (2004) Identification of a novel receptor-like protein kinase that interacts with a geminivirus nuclear shuttle protein. Virology 318:24-31

Más P, Beachy RN (1999) Replication of Tobacco mosaic virus on endoplasmic reticulum and role of the cytoskeleton and virus movement in intracellular distribution of viral RNA. J Cell Biol 147:945-958

Matsushita Y, Hanazawa K, Yoshioka K, Oguchi T, Kawakami S, Watanabe Y, Nishiguchi M, Nyunoya H (2000) In vitro phosphorylation of the movement protein of Tomato mosaic tobamovirus by a cellular kinase. J Gen Virol 81:2095-2102

Matsushita Y, Deguchi M, Youda M, Nishiguchi M, Nyunoya H (2001) The Tomato mosaic tobamovirus movement protein interacts with a putative transcriptional coactivator KELP. Mol Cells 12:57-66

Matsushita M, Miyakawa O, Deguchi M, Nishiguchi M, Nyunoya H (2002) Cloning of a tobacco cDNA coding for a putative transcriptional coactivator MBF1 that interacts with the Tomato mosaic virus movement protein. J Exp Bot 53:1531-1532

Matsushita Y, Ohshima M, Yoshioka K, Nishiguchi M, Nyunoya H (2003) The catalytic subunit of protein kinase CK2 phosphorylates in vitro the movement protein of Tomato mosaic virus. J Gen Virol 84:497-505

McCauley M, Hepler PK (1992) Cortical ultrastructure of freezesubstituted protonemata of the moss Funaria hygrometrica. Protoplasma 169:168-178

McGarry RC, Barron YD, Carvalho MF, Hill JE, Gold D, Cheung E, Kraus WL, Lazarowitz SG (2003) A novel Arabidopsis acetyltransferase interacts with the geminivirus movement protein NSP. Plant Cell 15:1605-1618

McLean BG, Zupan J, Zambryski PC (1995) Tobacco mosaic virus movement protein associates with the cytoskeleton in tobacco plants. Plant Cell 7:2101-2114

Meshi T, Watanabe Y, Saito T, Sugimoto A, Maeda T, Okada Y (1987) Function of the $30 \mathrm{kd}$ protein of Tobacco mosaic virus: involvement in cell-to-cell movement and dispensability for replication. EMBO J 6:2557-2563

Modena NA, Zelada AM, Conte F, Mentaberry A (2008) Phosphorylation of the TGBp1 movement protein of Potato virus $X$ by a Nicotiana tabacum CK2-like activity. Virus Res 137:16-23

Molnar A, Melnyk CW, Bassett A, Hardcastle TJ, Dunn R, Baulcombe DC (2010) Small silencing RNAs in plants are mobile and direct epigenetic modification in recipient cells. Science 328:872-875

Moore P, Fenczik CA, Deom CM, Beachy RN (1992) Developmental changes in plasmodesmata in transgenic tobacco expressing the movement protein of Tobacco mosaic virus. Protoplasma 170:115-127

Morozov SY, Solovyev AG (2003) Triple gene block: modular design of a multifunctional machine for plant virus movement. J Gen Virol 84:1351-1366

Morozov SY, Fedorkin ON, Juttner G, Schiemann J, Baulcombe DC, Atabekov JG (1997) Complementation of Potato virus X mutant mediated by bombardment of plant tissues with cloned viral movement protein genes. J Gen Virol 78:2077-2081

Nagano H, Mise K, Furosawa I, Okuno T (2001) Conversion in the requirement of coat protein in cell-to-cell movement mediated by the cucumber mosaic virus movement protein. J Virol 75:80458053

Nagpal P, Quatrano RS (1999) Isolation and characterization of a cDNA clone from Arabidopsis thaliana with partial sequence similarity to integrins. Gene 230:33-40

Nishiguchi M, Motoyoshi F, Oshima N (1978) Behaviour of a temperature-sensitive strain of Tobacco mosaic virus in tomato leaves and protoplasts. J Gen Virol 39:53-61

Noris E, Vaira AM, Caciagli P, Masenga V, Gronenborn B, Accotto GP (1998) Amino acids in the capsid protein of Tomato yellow leaf curl virus that are crucial for systemic infection, particle formation, and insect transmission. J Virol 72:10050-10057

Ohno T, Takamatsu N, Meshi T, Okada Y, Nishigushi M, Kiho Y (1983) Single amino acid substitution in $30 \mathrm{k}$ protein of TMV defective in virus transport function. Virology 131:255-258

Oparka KJ (1994) Plasmolysis: new insights into an old process. New Phytol 126:571-591

Oparka KJ, Prior DAM, Santa Cruz S, Padgett HS, Beachy RN (1997) Gating of epidermal plasmodesmata is restricted to the leading edge of expanding infection sites of Tobacco mosaic virus. Plant J 12:781-789

Oparka KJ, Roberts AG, Boevink P, Santa Cruz S, Roberts I, Pradel KS, Imlau A, Kotlizky G, Sauer N, Epel B (1999) Simple, but not branched, plasmodesmata allow the nonspecific trafficking of proteins in developing tobacco leaves. Cell 97:743-754 
Ouko M, Sambade A, Brandner K, Niehl A, Peña E, Heinlein M, Nick $P$ (2010) Tobacco mutants with reduced microtubule dynamics are less susceptible to TMV. Plant J 62:829-839

Padgett HS, Epel BL, Kahn TW, Heinlein M, Watanabe Y, Beachy RN (1996) Distribution of tobamovirus movement protein in infected cells and implications for cell-to-cell spread of infection. Plant $\mathrm{J}$ 10:1079-1088

Padidam M, Beachy RN, Fauquet CM (1995) Tomato leaf curl geminivirus from India has a bipartite genome and coat protein is not essential for infectivity. J Gen Virol 76:25-35

Perbal M-C, Haughn G, Saedler H, Schwarz-Sommer Z (1996) Nonautonomous function of Antirrhinum floral homeotic proteins DEFICIENS and GLOBOSA is exerted by their polar cell-to-cell trafficking. Development 122:3433-3441

Perbal M-C, Thomas CL, Maule AJ (1993) Cauliflower mosaic virus gene I product $(\mathrm{P} 1)$ forms tubular structures which extend from the surface of infected protoplasts. Virology 195:281-285

Pont-Lezica RF, McNally JG, Pickard BG (1993) Wall-to-membrane linkers in onion epidermis: some hypotheses. Plant Cell Environ 16:111-123

Pouwels J, Van Der Krogt GN, Van Lent J, Bisseling T, Wellink J (2002) The cytoskeleton and the secretory pathway are not involved in targeting the Cowpea mosaic virus movement protein to the cell periphery. Virology 297:48-56

Pouwels J, van der Velden T, Willemse J, Borst JW, van Lent J, Bisseling T, Wellink J (2004) Studies on the origin and structure of tubules made by the movement protein of Cowpea mosaic virus. J Gen Virol 85:3787-3796

Prokhnevsky AI, Peremyslov VV, Dolja VV (2005) Actin cytoskeleton is involved in targeting of a viral Hsp70 homolog to the cell periphery. J Virol 79:14421-14428

Radford JE, White RG (1998) Localization of a myosin-like protein to plasmodesmata. Plant J 14:743-750

Raffaele S, Bayer E, Lafarge D, Cluzet S, German Retana S, Boubekeur T, Leborgne-Castel N, Carde JP, Lherminier J, Noirot E, Satiat-Jeunemaitre B, Laroche-Traineau J, Moreau P, Ott T, Maule AJ, Reymond P, Simon-Plas F, Farmer EE, Bessoule JJ, Mongrand S (2009) Remorin, a solanaceae protein resident in membrane rafts and plasmodesmata, impairs Potato virus $X$ movement. Plant Cell 21:1541-1555

Rao AL, Cooper B, Deom CM (1998) Defective movement of viruses in the family bromoviridae is differentially complemented in Nicotiana benthamiana expressing tobamovirus or dianthovirus movement proteins. Phytopathology 88:666-672

Reichel C, Beachy RN (2000) Degradation of the Tobacco mosaic virus movement protein by the $26 \mathrm{~S}$ proteasome. J Virol 74:3330-3337

Reichelt S, Knight AE, Hodge TP, Baluska F, Samaj J, Volkmann D, Kendrick-Jones J (1999) Characterization of the unconventional myosin VIII in plant cells and its localization at the postcytokinetic cell wall. Plant J 19:555-569

Rhee Y, Tzfira T, Chen MH, Waigmann E, Citovsky V (2000) Cell-tocell movement of Tobacco mosaic virus: enigmas and explanations. Mol Plant Pathol 1:33-39

Rigden JE, Krake LR, Rezaian MA, Dry IB (1994) ORF C4 of Tomato leaf curl geminivirus is a determinant of symptom severity. Virology 204:847-850

Ritzenthaler C, Schmidt A-C, Michler P, Stussi-Garaud C, Pinck L (1995) Grapevine fanleaf nepovirus putative movement protein is involved in tubule formation in vivo. Mol Plant Microbe Interact $8: 379-387$

Robaglia C, Caranta C (2006) Translation initiation factors: a weak link in plant RNA virus infection. Trends Plant Sci 11:40-45

Roberts IM, Wang D, Findlay K, Maule AJ (1998) Ultrastructural and temporal observations of the potyvirus cylindrical inclusions
(CIs) show that the CI protein acts transiently in aiding virus movement. Virology 245:173-181

Roberts IM, Wang D, Thomas CL, Maule AJ (2003) Seed transmission of Pea seed borne mosaic virus in pea exploits novel symplastic pathways and is, in part, dependent upon chance. Protoplasma 222:31-43

Rodríguez-Cerezo E, Findlay K, Shaw JG, Lomonossoff GP, Qiu SG, Linstead P, Shanks M, Risco C (1997) The coat and cylindrical inclusion proteins of a potyvirus are associated with connections between plant cells. Virology 236:296-306

Rojas MR, Hagen C, Lucas WJ, Gilbertson RL (2005) Exploiting chinks in the plant's armor: evolution and emergence of geminiviruses. Annu Rev Phytopathol 43:361-394

Rojas MR, Jiang H, Salati R, Xoconostle-Cazares B, Sudarshana MR, Lucas WJ, Gilbertson RL (2001) Functional analysis of proteins involved in movement of the monopartite begomovirus, Tomato yellow leaf curl virus. Virology 291:110-125

Rojas MR, Zerbini M, Allison RF, Gilbertson RL, Lucas WJ (1997) Capsid protein and helper component-proteinase function as potyvirus cell-to-cell movement proteins. Virology 237:283-295

Ruiz-Medrano R, Xoconostle-Cazares B, Kragler F (2004) The plasmodesmatal transport pathway for homeotic proteins, silencing signals and viruses. Curr Opin Plant Biol 7:641-650

Ruggenthaler P, Fichtenbauer D, Krasensky J, Jonak C, Waigmann E (2009) Microtubule-associated protein AtMPB2C plays a role in organization of cortical microtubules, stomata patterning, and tobamovirus infectivity. Plant Physiol 149:1354-1365

Runions J, Brach T, Kuhner S, Hawes C (2006) Photoactivation of GFP reveals protein dynamics within the endoplasmic reticulum membrane. J Exp Bot 57:43-50

Sagi G, Katz A, Guenoune-Gelbart D, Epel BL (2005) Class 1 reversibly glycosylated polypeptides are plasmodesmalassociated proteins delivered to plasmodesmata via the Golgi apparatus. Plant Cell 17:1788-1800

Sambade A, Brandner K, Hofmann C, Seemanpillai M, Mutterer J, Heinlein M (2008) Transport of TMV movement protein particles associated with the targeting of RNA to plasmodesmata. Traffic 9:2073-2088

Sambade A, Heinlein M (2009) Approaching the cellular mechanism that supports the intercellular spread of Tobacco mosaic virus. Plant Signal Behav 4:35-38

Sanchez-Navarro JA, Herranz MC, Pallas V (2006) Cell-to-cell movement of Alfalfa mosaic virus can be mediated by the movement proteins of Ilar-, bromo-, cucumo-, tobamo- and comoviruses and does not require virion formation. Virology 346:66-73

Sanderfoot AA, Ingham DJ, Lazarowitz SG (1996) A viral movement protein as a nuclear shuttle. The geminivirus BR1 movement protein contains domains essential for interaction with BL1 and nuclear localization. Plant Physiol 110:23-33

Santa Cruz S, Roberts AG, Prior DAM, Chapman S, Oparka KJ (1998) Cell-to-cell and phloem-mediated transport of Potato virus $X$ : the role of virions. Plant Cell 10:495-510

Sasaki N, Kaido M, Okuno T, Mise K (2005) Coat proteinindependent cell-to-cell movement of bromoviruses expressing Brome mosaic virus movement protein with an adaptation-related amino acid change in the central region. Arch Virol 150:12311240

Schaad MC, Anderberg RJ, Carrington JC (2000) Strain-specific interaction of the Tobacco etch virus NIa protein with the translation initiation factor eIF4E in the yeast two-hybrid system. Virology 273:300-306

Seemanpillai M, Elamawi R, Ritzenthaler C, Heinlein M (2006) Challenging the role of microtubules in Tobacco mosaic virus movement by drug treatments is disputable. J Virol 80:67126715 
Seksek O, Biwersi J, Verkman AS (1997) Translational diffusion of macromolecule-sized solutes in cytoplasm and nucleus. J Cell Biol 138:131-142

Selth LA, Dogra SC, Rasheed MS, Randles JW, Rezaian MA (2006) Identification and characterization of a host reversibly glycosylated peptide that interacts with the Tomato leaf curl virus V1 protein. Plant Mol Biol 61:297-310

Senchou V, Weide R, Carrasco A, Bouyssou H, Pont-Lezica R, Govers F, Canut H (2004) High affinity recognition of a Phytophthora protein by Arabidopsis via an RGD motif. Cell Mol Life Sci 61:502-509

Shimizu T, Yoshii A, Sakurai K, Hamada K, Yamaji Y, Suzuki M, Namba S, Hibi T (2009) Identification of a novel tobacco DnaJlike protein that interacts with the movement protein of Tobacco mosaic virus. Arch Virol 154:959-967

Silhavy D, Burgyan J (2004) Effects and side-effects of viral RNA silencing suppressors on short RNAs. Trends Plant Sci 9:76-83

Sit TL, AbouHaidir MG (1993) Infectious RNA transcripts derived from cloned cDNA of Papaya mosaic virus: Effect of mutations to the capsid and polymerase proteins. J Gen Virol 74:1133-1140

Soellick TR, Uhrig JF, Bucher GL, Kellmann JW, Schreier PH (2000) The movement protein NSm of Tomato spotted wilt tospovirus: RNA binding, interaction with TSWV N protein, and identification of interacting plant proteins. Proc Natl Acad Sci USA 97:2373-2378

Sokolova M, Prufer D, Tacke E, Rohde W (1997) The Potato leafroll virus $17 \mathrm{k}$ movement protein is phosphorylated by a membraneassociated protein kinase from potato with biochemical features of protein kinase C. FEBS Lett 400:201-205

Solovyev AG, Stroganova TA, AAj Z, Fedorkin ON, Schiemann J, Morozov SY (2000) Subcellular sorting of small membraneassociated triple gene block proteins: TGBp3-assisted targeting of TGBp2. Virology 269:113-127

Sparkes I, Runions J, Hawes C, Griffing L (2009) Movement and remodeling of the endoplasmic reticulum in nondividing cells of tobacco leaves. Plant Cell 21:3937-3949

Storms MMH, Kormelink R, Peters D, van Lent JWM, Goldbach RW (1995) The nonstructural NSm protein of Tomato spotted wilt virus induces tubular structures in plant and insect cells. Virology 214:485-493

Su S, Liu Z, Chen C, Zhang Y, Wang X, Zhu L, Miao L, Wang XC, Yuan M (2010) Cucumber mosaic virus movement protein severs actin filaments to increase the plasmodesmal size exclusion limit in tobacco. Plant Cell 22:1373-1387

Sun Y, Qian H, Xu XD, Han Y, Yen LF, Sun DY (2000) Integrin-like proteins in the pollen tube: detection, localization and function. Plant Cell Physiol 41:1136-1142

Szécsi J, Ding XS, Lim CO, Bendahmane M, Cho MJ, Nelson RS, Beachy RN (1999) Development of Tobacco mosaic virus infection sites in Nicotiana benthamiana. Mol Plant Microbe Interact 2:143-152

Tagami Y, Watanabe Y (2007) Effects of brefeldin A on the localization of tobamovirus movement protein and cell-to-cell movement of the virus. Virology 361:133-140

Tagami Y, Inaba N, Kutsuna N, Kurihara Y, Watanabe Y (2007) Specific enrichment of miRNAs in Arabidopsis thaliana infected with Tobacco mosaic virus. DNA Res 14:227-233

Tamai A, Kubota K, Nagano H, Yoshii M, Ishikawa M, Mise K, Meshi T (2003) Cucumovirus- and bromovirus-encoded movement functions potentiate cell-to-cell movement of tobamo- and potexviruses. Virology 315:56-67

Taoka K, Ham BK, Xoconostle-Cazares B, Rojas MR, Lucas WJ (2007) Reciprocal phosphorylation and glycosylation recognition motifs control NCAPP1 interaction with pumpkin phloem proteins and their cell-to-cell movement. Plant Cell 19:18661884
Thomas CL, Maule AJ (1995) Identification of structural domains within the Cauliflower mosaic virus movement protein by scanning deletion mutagenesis and epitope tagging. Plant Cell 7:561-572

Thomas CL, Bayer EM, Ritzenthaler C, Fernandez-Calvino L, Maule AJ (2008) Specific targeting of a plasmodesmal protein affecting cell-to-cell communication. PLoS Biol 6:e7

Tilsner J, Cowan GH, Roberts AG, Chapman SN, Ziegler A, Savenkov E, Torrance L (2010) Plasmodesmal targeting and intercellular movement of Potato mop-top pomovirus is mediated by a membrane anchored tyrosine-based motif on the lumenal side of the endoplasmic reticulum and the C-terminal transmembrane domain in the TGB3 movement protein. Virology 402:4151

Tomenius K, Clapham D, Meshi T (1987) Localization by immunogold cytochemistry of the virus-coded $30 \mathrm{~K}$ protein in plasmodesmata of leaves infected with Tobacco mosaic virus. Virology 160:363-371

Trutnyeva K, Bachmaier R, Waigmann E (2005) Mimicking carboxyterminal phosphorylation differentially effects subcellular distribution and cell-to-cell movement of Tobacco mosaic virus movement protein. Virology 332:563-577

Tucker EB (1990) Calcium-loaded 1, 2-bis(2-aminophenoxy)ethane$\mathrm{N}, \mathrm{N}, \mathrm{N}$, N'-tetraacetic acid blocks cell-to-cell diffusion of carboxyfluorescein in staminal hairs of Setcreasea purpurea. Planta 182:34-38

Tucker EB (1993) Azide treatment enhances cell-to-cell diffusion in staminal hairs of Setcreasea purpurea. Protoplasma 174:45-49

Tucker EB, Boss WF (1996) Mastoparan induced intracellular $\mathrm{Ca}^{2+}$ fluxes may regulate cell-to-cell communication in plants. Plant Physiol 111:459-467

Turmel M, Otis C, Lemieux C (2006) The chloroplast genome sequence of Chara vulgaris sheds new light into the closest green algal relatives of land plants. Mol Biol Evol 23:1324-1338

Tyulkina LG, Karger EM, Sheveleva AA, Atabekov JG (2010) Binding of monoclonal antibodies to the movement protein (MP) of Tobacco mosaic virus: influence of subcellular MP localization and phosphorylation. J Gen Virol 91:16211628

Tzfira T, Rhee Y, Chen M-H, Kunik T, Citovsky V (2000) Nucleic acid transport in plant-microbe interactions: the molecules that walk through the walls. Annu Rev Microbiol 54:187-219

Ueda H, Yokota E, Kutsuna N, Shimada T, Tamura K, Shimmen T, Hasezawa S, Dolja VV, Hara-Nishimura I (2010) Myosindependent endoplasmic reticulum motility and F-actin organization in plant cells. Proc Natl Acad Sci USA 107:6894-6899

van Bargen S, Salchert K, Paape M, Piechulla B, Kellmann J-W (2001) Interactions between Tomato spotted wilt virus movement protein and plant proteins showing homologies to myosin, kinesin, and DNAJ-like chaperones. Plant Physiol Biochem 39:1083-1093

van der Wel N (2000) Interaction between the Alfalfa mosaic virus movement protein and plasmodesmata. $\mathrm{PhD}$. thesis Agricultural University, Wageningen, The Netherlands

van der Wel NN, Goldbach R, van Lent J (1998) The movement protein and coat protein of Alfalfa mosaic virus accumulate in structurally modified plasmodesmata. Virology 244:322329

van Lent J, Storms M, van der Meer F, Wellink J, Goldbach R (1991) Tubular structures involved in movement of Cowpea mosaic virus are also formed in infected cowpea protoplasts. J Gen Virol $72: 2615-2623$

Verchot-Lubicz J (2005) A new cell-to-cell transport model for potexviruses. Mol Plant Microbe Interact 18:283-290

Verchot-Lubicz J, Ye CM, Bamunusinghe D (2007) Molecular biology of potexviruses: recent advances. J Gen Virol 88:1643-1655 
Vogel F, Hofius D, Sonnewald U (2007) Intracellular trafficking of Potato leafroll virus movement protein in transgenic Arabidopsis. Traffic 8:1205-1214

Vogler H, Akbergenov R, Shivaprasad PV, Dang V, Fasler M, Kwon MO, Zhanybekova S, Hohn T, Heinlein M (2007) Modification of small RNAs associated with suppression of RNA silencing by tobamovirus replicase protein. J Virol 81:10379-10388

Vogler H, Kwon MO, Dang V, Sambade A, Fasler M, Ashby J, Heinlein M (2008) Tobacco mosaic virus movement protein enhances the spread of RNA silencing. PLoS Pathog 4:e1000038

Voinnet O, Lederer C, Baulcombe DC (2000) A viral movement protein prevents spread of the gene silencing signal in Nicotiana benthamiana. Cell 103:157-167

Waigmann E, Zambryski P (1995) Tobacco mosaic virus movement protein-mediated protein transport between trichome cells. Plant Cell 7:2069-2079

Waigmann E, Lucas W, Citovsky V, Zambryski P (1994) Direct functional assay for Tobacco mosaic virus cell-to-cell movement protein and identification of a domain involved in increasing plasmodesmal permeability. Proc Natl Acad Sci USA 91:1433-1437

Waigmann E, Chen M-H, Bachmeier R, Ghoshroy S, Citovsky V (2000) Regulation of plasmodesmal transport by phosphorylation of Tobacco mosaic virus cell-to-cell movement protein. EMBO J 19:4875-4884

Watanabe Y, Emori Y, ooshika I, Meshi T, Ohno T, Okada Y (1984) Synthesis of TMV-specific RNAs and proteins at the early stage of infection in tobacoo protoplasts: transient expression of $30 \mathrm{k}$ protein and its mRNA. Virology 133:18-24

Watanabe Y, Meshi T, Okada Y (1992) In vivo phosphorylation of the 30$\mathrm{kDa}$ protein of Tobacco mosaic virus. FEBS Lett 313:181-184

Wei T, Zhang C, Hong J, Xiong R, Kasschau KD, Zhou X, Carrington JC, Wang (2010) Formation of complexes at plasmodesmata for potyvirus intercellular movement is mediated by the viral protein P3N-PIPO. PLoS Pathog 6: e1000962

Wellink J, van Lent JW, Verver J, Sijen T, Goldbach RW, van Kammen A (1993) The Cowpea mosaic virus M RNA-encoded 48-kilodalton protein is responsible for induction of tubular structures in protoplasts. J Virol 67:3660-3664

White RG, Badelt K, Overall RL, Vesk M (1994) Actin associated with plasmodesmata. Protoplasma 180:169-184
Whitham SA, Quan S, Chang HS, Cooper B, Estes B, Zhu T, Wang X, Hou YM (2003) Diverse RNA viruses elicit the expression of common sets of genes in susceptible Arabidopsis plants. Plant J $33: 271-283$

Wieczorek A, Sanfaçon H (1993) Characterization and subcellular location of Tomato rigspot nepovirus putative movement protein. Virology 194:734-742

Winter N, Kollwig G, Zhang S, Kragler F (2007) MPB2C, a microtubule-associated protein, regulates non-cell-autonomy of the homeodomain protein KNOTTED1. Plant Cell 19:3001-3018

Wittmann S, Chatel H, Fortin MG, Laliberte JF (1997) Interaction of the viral protein genome linked of Turnip mosaic potyvirus with the translational eukaryotic initiation factor (iso) 4E of Arabidopsis thaliana using the yeast two-hybrid system. Virology 234:84-92

Wolf S, Deom CM, Beachy RN, Lucas WJ (1989) Movement protein of Tobacco mosaic virus modifies plasmodesmatal size exclusion limit. Science 246:377-379

Wright KM, Wood NT, Roberts AG, Chapman S, Boevink P, Mackenzie KM, Oparka KJ (2007) Targeting of TMV movement protein to plasmodesmata requires the actin/ER network; evidence from FRAP. Traffic 8:21-31

Wu X, Weigel D, Wigge PA (2002) Signaling in plants by intercellular RNA and protein movement. Genes Dev 16:151-158

Wu X, Dinneny JR, Crawford KM, Rhee Y, Citovsky V, Zambryski PC, Weigel D (2003) Modes of intercellular transcription factor movement in the Arabidopsis apex. Development 130:37353745

Yaholom A, Lando R, Katz A, Epel BL (1998) A calcium-dependent protein kinase is associated with maize mesocotyl plasmodesmata. J Plant Physiol 153:354-362

Yoo BC, Kragler F, Varkonyi-Gasic E, Haywood V, Archer-Evans S, Lee YM, Lough TJ, Lucas WJ (2004) A systemic small RNA signaling system in plants. Plant Cell 16:1979-2000

Yoshioka K, Matsushita Y, Kasahara M, Konagaya K, Nyunoya H (2004) Interaction of Tomato mosaic virus movement protein with tobacco RIO kinase. Mol Cells 17:223-229

Zimmern D (1983) An extended secondary structure model for the TMV assembly origin, and its correlation with protection studies and an assembly defective mutant. EMBO J 2:1901-1907 